OPEN ACCESS

Edited by:

Marlon R. Lewis,

Dalhousie University, Canada

Reviewed by:

Stanley Kim Juniper,

University of Victoria, Canada Robert Blasiak,

Stockholm University, Sweden

*Correspondence: Nicholas J. Bax nic.bax@csiro.au

Patricia Miloslavich pmilos@usb.ve

Specialty section:

This article was submitted to Ocean Observation,

a section of the journal

Frontiers in Marine Science

Received: 21 December 2018 Accepted: 25 June 2019 Published: 17 July 2019

Citation:

Bax NJ, Miloslavich $P$, Muller-Karger FE, Allain V, Appeltans W, Batten SD, Benedetti-Cecchi L, Buttigieg PL,

Chiba S, Costa DP, Duffy JE, Dunn DC, Johnson CR, Kudela RM,

Obura D, Rebelo L-M, Shin Y-J, Simmons SE and Tyack PL (2019) A Response to Scientific and Societal

Needs for Marine Biological Observations. Front. Mar. Sci. 6:395. doi: 10.3389/fmars.2019.00395

\section{A Response to Scientific and Societal Needs for Marine Biological Observations}

\author{
Nicholas J. Bax ${ }^{1,2 *}$, Patricia Miloslavich ${ }^{1,2,3 *}$, Frank Edgar Muller-Karger ${ }^{4}$, Valerie Allain ${ }^{5}$, \\ Ward Appeltans ${ }^{6}$, Sonia Dawn Batten ${ }^{7}$, Lisandro Benedetti-Cecchi ${ }^{8}$, \\ Pier Luigi Buttigieg ${ }^{9}$, Sanae Chiba ${ }^{10,11}$, Daniel Paul Costa ${ }^{12}$, J. Emmett Duffy ${ }^{13}$, \\ Daniel C. Dunn ${ }^{14}$, Craig Richard Johnson'2, Raphael M. Kudela ${ }^{15}$, David Obura' ${ }^{16,17}$, \\ Lisa-Maria Rebelo ${ }^{18}$, Yunne-Jai Shin ${ }^{19,20}$, Samantha Elisabeth Simmons ${ }^{21}$ and \\ Peter Lloyd Tyack ${ }^{22}$ \\ ${ }^{1}$ Oceans and Atmosphere, CSIRO, Hobart, TAS, Australia, ${ }^{2}$ Institute for Marine and Antarctic Studies, University \\ of Tasmania, Hobart, TAS, Australia, ${ }^{3}$ Departamento de Estudios Ambientales, Universidad Simón Bolívar, Caracas, \\ Venezuela, ${ }^{4}$ Institute for Marine Remote Sensing, College of Marine Science, University of South Florida, St. Petersburg, \\ St. Petersburg, FL, United States, ${ }^{5}$ Secretariat of the Pacific Community, Noumea, France, ${ }^{6}$ Intergovernmental \\ Oceanographic Commission of UNESCO, IOC Project Office for IODE, Ostend, Belgium, ${ }^{7}$ The CPR Survey-MBA, Nanaimo, \\ BC, Canada, ${ }^{8}$ Department of Biology, University of Pisa, CoNISMa, Pisa, Italy, ${ }^{9} \mathrm{Helmholtz}$ Zentrum für Polar- und \\ Meeresforschung, Alfred Wegener Institut, Bremerhaven, Germany, ${ }^{10}$ JAMSTEC, Yokohama, Japan, ${ }^{11}$ UNEP-WCMC, \\ Cambridge, United Kingdom, ${ }^{12}$ Department of Ecology and Evolutionary Biology, University of California, Santa Cruz, Santa \\ Cruz, CA, United States, ${ }^{13}$ Smithsonian, Washington, DC, United States, ${ }^{14}$ Nicholas School of the Environment, Duke \\ University, Durham, NC, United States, ${ }^{15}$ Ocean Sciences Department, University of California, Santa Cruz, Santa Cruz, CA, \\ United States, ${ }^{16}$ Coastal Oceans Research and Development in the Indian Ocean (CORDIO East Africa), Mombasa, Kenya, \\ ${ }^{17}$ Global Change Institute, The University of Queensland, Brisbane, QLD, Australia, ${ }^{18}$ International Water Management \\ Institute, Regional Office for SE Asia and The Mekong, Vientiane, Laos, ${ }^{19}$ MARBEC (IRD, Univ. Montpellier, IFREMER, \\ CNRS), Montpellier, France, ${ }^{20}$ Department of Biological Sciences, Ma-Re Institute, University of Cape Town, Cape Town, \\ South Africa, ${ }^{21}$ Marine Mammal Commission, Bethesda, MD, United States, ${ }^{22}$ Marine Biological Association, \\ Nanaimo, BC, Canada
}

Development of global ocean observing capacity for the biological EOVs is on the cusp of a step-change. Current capacity to automate data collection and processing and to integrate the resulting data streams with complementary data, openly available as FAIR data, is certain to dramatically increase the amount and quality of information and knowledge available to scientists and decision makers into the future. There is little doubt that scientists will continue to expand their understanding of what lives in the ocean, where it lives and how it is changing. However, whether this expanding information stream will inform policy and management or be incorporated into indicators for national reporting is more uncertain. Coordinated data collection including open sharing of data will help produce the consistent evidence-based messages that are valued by managers. The GOOS Biology and Ecosystems Panel is working with other global initiatives to assist this coordination by defining and implementing Essential Ocean Variables. The biological EOVs have been defined, are being updated following community feedback, and their implementation is underway. In 2019, the coverage and precision of a global ocean observing system capable of addressing key questions for the next decade will be quantified, and its potential to support the goals of the UN Decade of Ocean Science for Sustainable Development identified. Developing a global 
ocean observing system for biology and ecosystems requires parallel efforts in improving evidence-based monitoring of progress against international agreements and the open data, reporting and governance structures that would facilitate the uptake of improved information by decision makers.

\section{Keywords: GOOS, capacity development, EOV, ocean observing, essential ocean variable, UN Decade,} Sustainable Development Goals

\section{INTRODUCTION}

The Earth, including its atmosphere, land, and ocean ecosystems is changing more rapidly than human societies have experienced in the past two millennia (Poloczanska et al., 2013; Rhein et al., 2013; Schmidtko et al., 2017; Stock et al., 2017). Changes in the ocean are occurring at many levels. There is substantial evidence of overfishing, affecting both target and non-target species (e.g., Watson et al., 2017), leading to population, community and ecosystem level impacts in coastal (Jennings and Kaiser, 1998), deep sea (Koslow et al., 2000) and pelagic environments (Crespo and Dunn, 2017). Shallow tropical coral species are experiencing widespread bleaching, predation such as by the crown of thorns starfish in the Pacific, or replacement by fast-growing algae because of nutrients and other pollutants introduced by humans in many localities (Hughes et al., 2017), affecting local community food security and tourism. Deep-sea coral communities are being affected by fishing and climate change (Williams et al., 2010; Thresher et al., 2011).

Current science and monitoring activities have provided clear evidence of changes at the scale of our planet attributable to intense human activities and complex and long-term changes in environmental parameters. These changes are impacting the distribution and phenology of marine biota (Poloczanska et al., 2013). Sustained monitoring of animal and plant populations and habitats is needed to characterize where and how fast these changes are occurring, where populations and communities are resilient to such change, and where losses of some species and the appearance of new species are impacting human health and the economy, both positively and negatively. This information will assist: (1) local communities to prepare and respond to coming changes; (2) national governments to manage adaptively across the domains of ecology, socioeconomics and governance; and (3) global institutions to develop appropriate policies and globally coordinated support. This will assist maritime nations to respond to our changing environment, while being confident that other nations are undertaking similar actions in word and deed. Sustained monitoring is needed to identify what works, what does not, and where future evidence-based investments are most likely to effect long-term positive change.

Many international treaties have highlighted the speed of current change in biological communities and the negative impacts that lack of action will have on sustainable development. Specifying and developing a sustained observing system that can improve knowledge for action at the many spatial scales of governance and ecosystem structure is no trivial task. It requires identifying the key questions, assessing existing observing system coverage and intensity, prioritization of future investments, capacity development and technology transfer. System coverage needs to be extended to the most critical areas for each issue, with regular reviews of system performance. Critically, the global system will need to attract substantial resourcing, often at the national level, if it is to provide the sustained observations that are needed to drive policy and support managed change.

Developing a global observing system for the biological ocean is fortunately becoming a technical reality. Sustained biological observation of the oceans began only 100 years ago, became regional in the 1930 s and underwent a notable rise in the mid-70s that has continued to the present day (Miloslavich et al., 2018a). Rapid technology development in automation and miniaturization are increasing the scale and scope of scientific endeavors thus making observing programs increasingly datarich, cost-effective and ultimately more likely to be sustained.

Some new technologies expand traditional data streams, while others open new ones. Thirty years of remote sensing support detailed analysis of trends in ocean color and surface productivity (e.g., Dunstan et al., 2018), while advances in artificial intelligence and machine learning provide increasingly rapid and consistent classification and processing of underwater imagery and marine fauna (Goetze et al., 2019). Advances in 'omics support new monitoring approaches such as Close-Kin Mark Recapture which can census adult populations without ever sampling an adult (Hillary et al., 2018), and environmental DNA which can identify species and populations from the water they swim in (Sigsgaard et al., 2016). Miniature genomic processors (e.g., nanopore sequencing, Brown et al., 2017) will soon be able to sequence DNA remotely on Autonomous vehicles including profiling floats and gliders, leading to a massive increase in information. Not all approaches will be suitable for monitoring but even they will improve our knowledge of system structure and function that will direct and assist interpretation of monitoring programs.

Developing a global biological monitoring system for the ocean also requires a cultural change in the way that marine scientists (especially biologists) share their data. We have an opportunity with the UN Decade of Ocean Science for Sustainable Development (UN Decade) to realize the expectation that making scientific data open and accessible under FAIR principles is the default for data platforms and researchers (Stall et al., 2019). A lasting legacy of the UN Decade would be if marine biologists were to share their data as openly as physical oceanographers do already.

In 2015, the Global Ocean Observing System of the Intergovernmental Oceanographic Commission of UNESCO (GOOS) identified the need to expand their role in ocean observing to the biological realm and added the Biology and Ecosystems Panel (BioEco) to the existing Physics and 
Biogeochemistry panels. GOOS has been among the groups leading the development of global sustained observations for physics and biogeochemistry, supporting the needs of science and policy through the IPCC among others.

In section "Introduction" of this paper, we review the process to date in identifying the biological Essential Ocean Variables (EOVs), and how the international community has been engaged in their validation, integration and implementation. Section "Building the Leadership and Community Support" identifies many of the (substantial) tasks remaining before a global ocean observing system for biology and ecosystems can become operational. A brief description of the need for each EOV, supporting EOVs, and the challenges and recommendations for their future development, including links to other important initiatives is provided in section "Status of Implementing the Biological EOVs.". Section "Organizational Structure and Challenges" identifies the complex scientific and reporting environment that continued EOV development will need to operate in and gain support from. Future developments and directions are briefly discussed in section "Future Directions and Developments.”

\section{BUILDING THE LEADERSHIP AND COMMUNITY SUPPORT}

The role of the GOOS panels is to identify and set the requirements for EOVs, followed by the development of a coordinated implementation strategy. Implementation is based on collection standards and the interoperability of data and information products. Once the Biology and Ecosystem Panel was established in 2015, it outlined an initial set of activities, targets and products (Figure 1).

The first task was to identify a set of biological EOVs guided by the Framework for Ocean Observing (Lindstrom et al., 2012). EOVs are selected to have high impact and high feasibility. EOV impact is defined as their relevance to solving science questions, addressing societal needs and their contribution to improved marine resource management. Feasibility required EOVs to be scientifically credible, technically practical and cost effective. To identify the biological EOVs, the panel adopted a process that (1) linked to international initiatives and issues, (2) was transparent, (3) was inclusive, and (4) was peer reviewed. Twenty-four international conventions and/or multilateral agreements relevant to marine life were surveyed in support of EOV selection. The current state of ocean observation networks and the uptake of EOVs in addressing societal and scientific issues were used to identify feasibility (Figure 2; Miloslavich et al., 2018a).

Biological EOVs (Table 1) focus on the status and change of ecosystem components (microbial communities, phytoplankton, zooplankton, fish, marine turtles, birds, mammals), and habitats (hard coral, seagrass, mangrove and macroalgae), with additional EOVs being developed as time and circumstances require (current emerging EOVs are for benthic invertebrate and microbes; Miloslavich et al., 2018a). A separate GOOS project is developing a Deep Ocean Observing Strategy (DOOS; Levin et al., 2019). This project will work with the three panels to identify

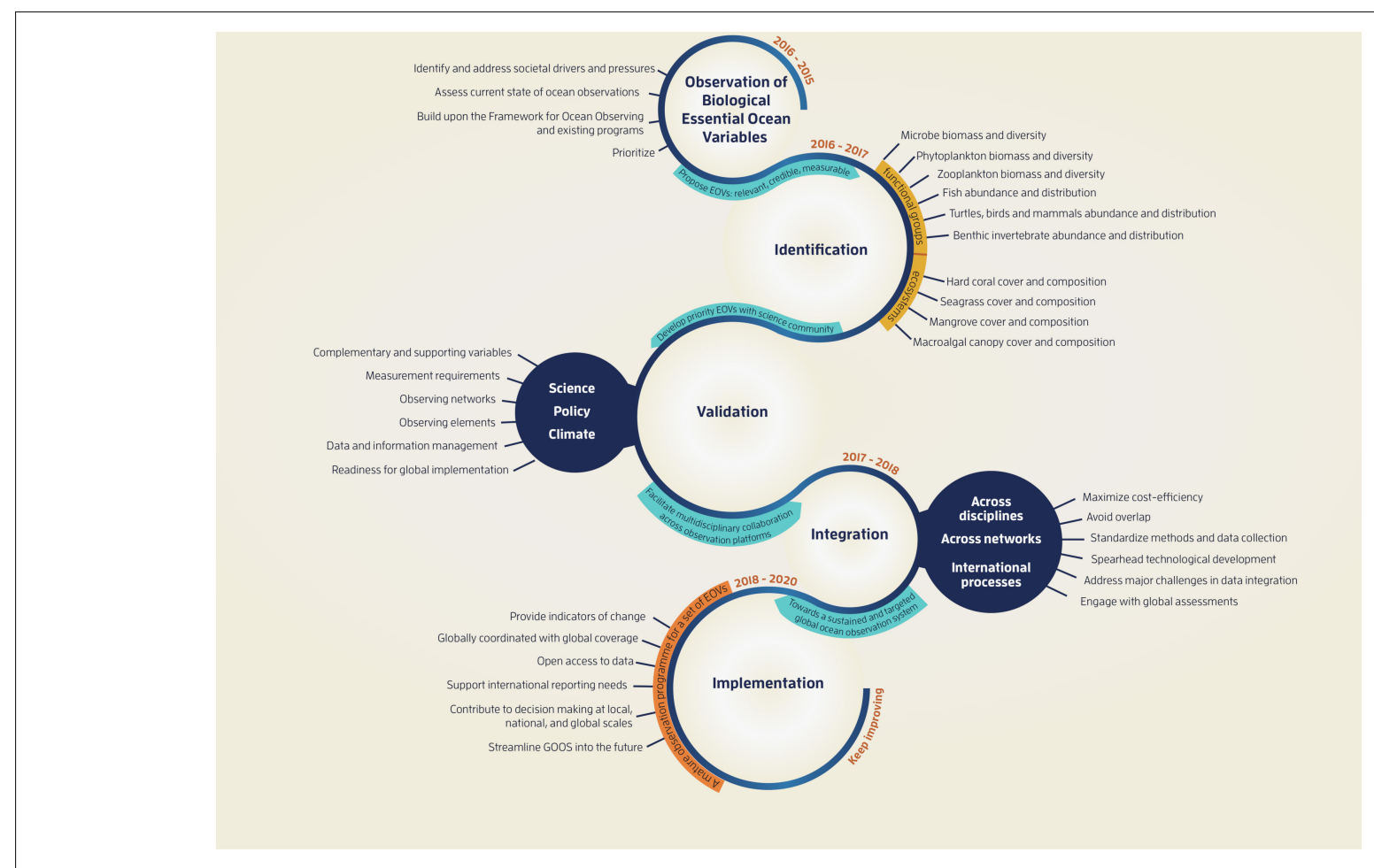

FIGURE 1 | Schematic of the tasks identified by the GOOS Biology and Ecosystems Panel to develop a sustained observing system. 


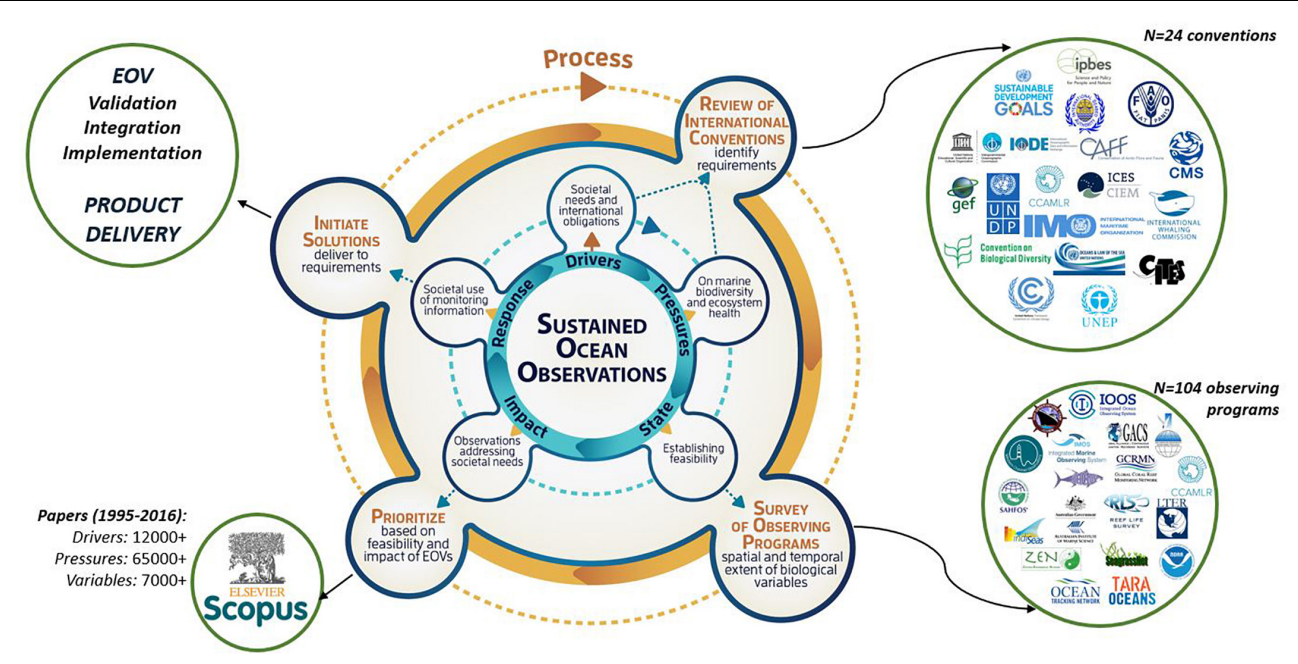

FIGURE 2 | Process used to identify the biological EOVs following the commonly applied Driver Pressure State Impact Response (DPSIR) model (updated from Miloslavich et al., 2018a).

TABLE 1 | Essential Ocean Variables identified for each GOOS panel.

\begin{tabular}{|c|c|c|}
\hline Physics & Biogeochemistry & Biology and ecosystems \\
\hline - Sea state & - Oxygen & - Phytoplankton biomass and diversity \\
\hline - Ocean surface stress & - Inorganic carbon & - Zooplankton biomass and diversity \\
\hline - Ocean surface heat flux & - Transient tracers & - Fish abundance and distribution \\
\hline - Sea ice & - Particulate matter & - Marine turtles, birds and mammals abundance and distribution \\
\hline - Sea surface height & - Nutrients & - Hard coral cover and composition \\
\hline - Sea surface temp & - Nitrous oxide & - Seagrass cover and composition \\
\hline - Subsurface temperature & - Dissolved organic carbon & - Mangrove cover and composition \\
\hline - Surface currents & - Ocean color & - Macroalgal cover and composition \\
\hline - Subsurface currents & - Stable carbon isotopes & - Microbe biomass and diversity (emerging) \\
\hline - Sea surface salinity & & - Invertebrate abundance and distribution (emerging) \\
\hline - Subsurface salinity & & - Ocean Sound \\
\hline
\end{tabular}

Subvariables provide further specification and are listed in the specification sheets (www.goosocean.org). DOOS is working with the panels to identify where modifications or additional EOVs are needed specifically for monitoring the deep ocean.

where existing EOVs need to be extended or new ones added. Cross-disciplinary EOVs including ocean color, and ocean sound are directly relevant to understand the physical, biogeochemical, and biological properties of the ocean but are housed in one of the three panels. There is an ongoing discussion of how human pressure EOVs (e.g., marine debris) could be developed, perhaps through linking to existing groups active in these areas.

The second task was to validate these biological EOVs with stakeholders to maximize the probability of their uptake and use by the scientific, climate and policy communities which could be quite different for each EOV. Scientific communication through refereed papers (Bax et al., 2018; Miloslavich et al., 2018a,b; Muller-Karger et al., 2018b), presentations at key conferences (e.g., the American Geophysical Union - Ocean Sciences Conference, the World Conference of Marine Biodiversity, the Effects of Climate Change on the World's Oceans International Symposium, the bi-annual conference of International Society for Microbial Ecology and many more specialized meetings), and the drafting of peer-reviewed technical specification sheets for each of the EOVs ${ }^{1}$ were part of the validation process. Several biological EOVs were taken up as Essential Climate Variables (ECVs), part of the Global Climate Observing System (GCOS) (World Meteorological Organization [WMO], 2016). Engagement with the policy makers was through joint workshops including groups with reporting and assessment responsibilities as well as country representatives likely to use the information for their own management and reporting (UNEP/CBD/SBSTTA/20/16/Page 121).

The third task was to integrate these biological EOVs within current observing efforts. Standard operating procedures and best practices for collecting, analysing and sharing information will increase scientific impact at regional and global levels and help justify building investment in a sustained observing system. An agreement was signed with the Marine Biodiversity Observation Network (MBON), a theme of the Group on Earth Observations Biodiversity Observation Network (GEO BON)

\footnotetext{
${ }^{1}$ http://www.goosocean.org/eov
} 
and the Ocean Biogeographic Information System (OBIS). This agreement supports the development of a globally coordinated and sustained observing system sharing open access data and best practices, and facilitating capacity development ${ }^{2}$. This group of three subsequently partnered with the GEO Blue Planet initiative.

Integration of biological EOVs with established observing networks, including some of the GOOS Regional Alliances (e.g., the US Integrated Ocean Observing System - IOOS, the Australian Integrated Marine Observing System - IMOS, and the Southern Ocean Observing System - SOOS), has started (Figure 3). Collaboration with other groups including Future Earth, the Research Coordination Network under the U.S. National Science Foundation, and working groups of the Scientific Committee for Oceanic Research (SCOR) (e.g., plankton, Boss et al., 2018) is developing. Integration of the three GOOS disciplines (physics, biogeochemistry and biology) is occurring through major ocean phenomena that require cross-disciplinary observation.

Implementation, the fourth task, is occurring through workshops for each EOV. GOOS panels do not have the capacity or technical resources to develop new observing networks, but through coordinating existing networks and platforms, aim to improve the comparability and openness of existing data collections. The workshops bring together teams of international experts to discuss how to develop a global, coordinated strategy for monitoring each $\mathrm{EOV}$, identify the relevant existing datasets and networks, review technological monitoring approaches and best practices, and identify gaps in geographic or system coverage that need to be addressed. Once the scope of the global network for an EOV is identified, the GOOS panels will work with existing networks and platforms to expand their scope of activities through technology transfer and targeted capacity development.

${ }^{2}$ http://www.iobis.org/documents/GOOS-BioEco-OBIS-GEOBON-MBON_ collaboration_SIGNED.pdf
Best practices are an important first step in being able to share data and relevant metadata in a meaningful fashion. Developing best practices requires international agreement, coordination, funding, publication and active promotion. GOOS, MBON, and others work with the Intergovernmental Oceanographic Commission (IOC) Ocean Best Practices Working Group to develop workflows to document, implement and continually update Best Practices for EOVs and identified subvariables. An essential component of best practices is promoting open data shared promptly. The lack of open data is one of the most significant impediments to developing a global observing system for ocean biology and ecosystems. Data sharing policies are particularly important for data that might be of commercial, cultural or other importance.

As of November 2018, three implementation workshops had taken place for coral, plankton and macroalgal EOVs. Workshops have been organized opportunistically in collaboration with other groups. The role of GOOS has been mostly to facilitate, coordinate and support integration within the different networks so that the EOVs are organized following a common framework and progressed to a more mature stage. For example, the coral EOV builds on long time efforts by the Global Coral Reef Monitoring Network (GCRMN), the zooplankton EOV builds on the Global Alliance of Continuous Plankton Recorders (GACs) and includes future automated technologies on global platforms, while the macroalgal EOV builds on a long history of individual coastal monitoring programs updated to include newer automated technologies.

\section{REMAINING TASKS}

The Panel has rapidly progressed through their tasks identified in the Framework for Ocean Observing (Lindstrom et al., 2012), since 2016, but much remains to be done, particularly for

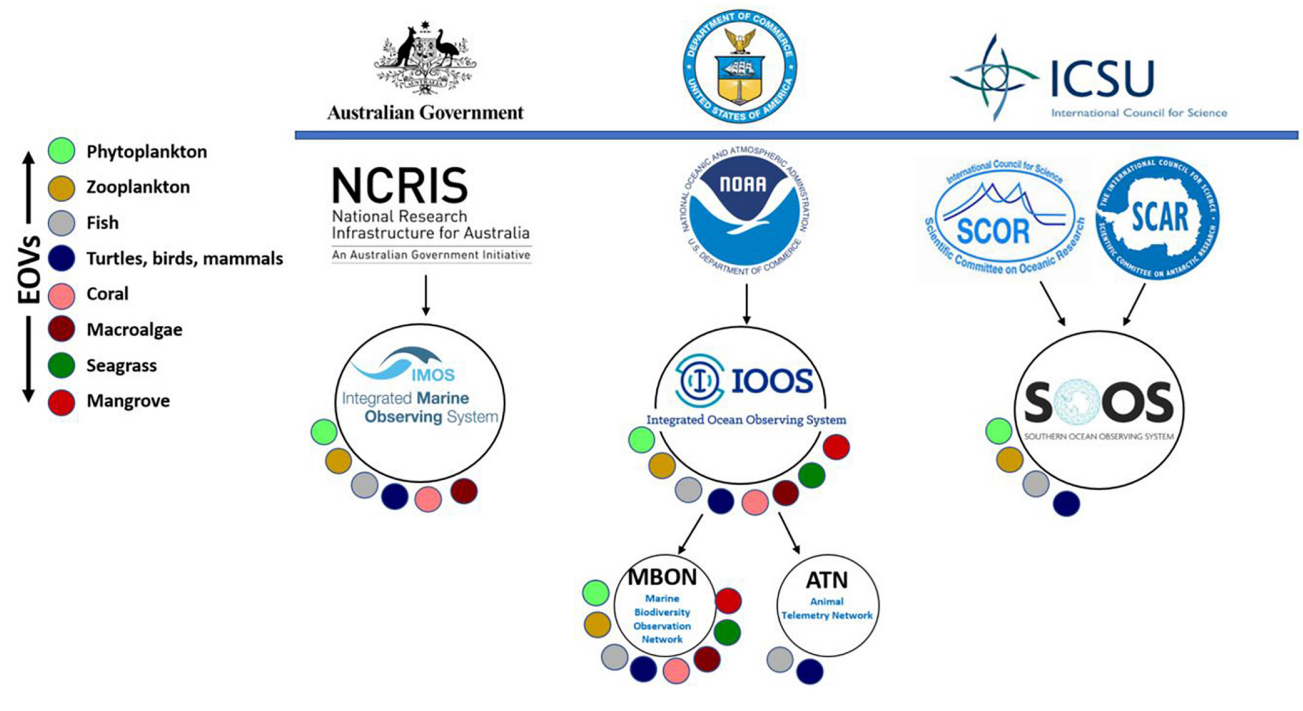

FIGURE 3 | Examples of links between some observing systems and the GOOS BioEco EOVs. 
validation, integration and implementation. EOV identification will be progressively refined, guided by new priorities or scientific advances (as is happening with the microbial EOV) and based on community feedback (as is happening for the deep ocean, Levin et al., 2019).

\section{Validation}

A critical next step is completing the identification of existing observing networks and elements and comparing this to the desired geographical and temporal coverage. The Panel will be working on this with additional experts supported by a PEGASuS (Future Earth/NCEAS) grant to identify priority gaps to target through the UN Decade. This will require a parallel task in data and information management to ensure that collected data are available for regional and global management and reporting.

\section{Integration}

A global ocean observing system is not something that one group is likely to achieve by itself. Ongoing coordination will be required to agree on best practices, improve efficiencies, fill gaps, and reduce any redundancies. Standard operating procedures and best practices do not have to be prescriptive, but do require attention to design, deployment and recording so that comparison of measurements made in different places or in time series to detect and accurately quantify change can be made and confidently communicated to decision makers and policy makers (Przeslawski et al., 2019).

Integration of the scientific, management, and policy environments is also needed to establish a global observing system that is relevant and supported. This will require improving how scientific information is used to support management and policy decisions at all levels of government. For example, indicators chosen for reporting against international conventions and agreements, such as SDG 14 or CBD biodiversity targets, are frequently based on lowest common denominator options so that all countries can participate. The marine science community needs to work within the policy environment to help develop more informative, quantitative indicators that provide direct information on trends in the state of the marine environment. Nested or hierarchical indicators so that countries can track their progress at the level in the hierarchy appropriate to their level of development is one approach to achieve greater relevance (Dunstan et al., 2016). Increasing the relevance of monitoring data to the management and policy environments will help incentivise and target capacity development and technology transfer.

\section{Implementation}

The UN Decade provides a useful time-frame and target to build the comprehensive and sustainable global ocean observing system for biology. This time-frame matches that for Agenda 2030, and the observing system will be able to support countries reporting against the Sustainable Development Goals. Improved consistency and improved access to data under FAIR principles will provide the means to answer scientific questions that no one institute could achieve. The UN Decade has an opportunity to shift the culture of science and data collection of marine biological data to one that is more open, more collaborative and has greater impact.

Improved capacity development and technology transfer will be required, especially if monitoring is to be sustained a common failing of many existing initiatives, especially in Least Developed Countries and Small Island Developing States. Linking capacity development and technology transfer to sustained monitoring may provide an opportunity provide enduring networks and connections between scientists in the developing and developed world that will keep scientists engaged over the long term (Bax et al., 2018). Improved ocean observing capacity will underpin the growth of the Blue Economy and is critical to sustainable development.

\section{Iteration}

A sustained global ocean observing system will require constant adjustment and tuning especially during its development stage, but also as new questions and ways of collecting information gain priority. Physical oceanographers have the advantage of globally integrating models, whereas many populations, species, and habitats are localized and require individual attention. Maintaining a backbone of sustained, consistent, and interoperable observations to monitor long-term change at the regional and global scale, while making the most of opportunities from more local studies will be one of the continuing challenges for sustained biological observation. It will be equally important to support, the aggregation of information from local to regional, and from regional to global reporting to improve the relevance and uptake of monitoring information (e.g., Harrison et al., 2018).

\section{STATUS OF IMPLEMENTING THE BIOLOGICAL EOVS}

\section{Phytoplankton Biomass and Diversity and Zooplankton Biomass and Diversity}

The plankton EOVs have been approached together as there is considerable overlap in expertise and monitoring networks. The scientific community has recognized the importance of understanding plankton abundance, diversity and productivity for centuries (Muller-Karger et al., 2014). Many of the ecosystem services supporting human activities in coastal and ocean waters depend on planktonic organisms, which represent the lowest trophic levels in the ocean and are key components of global biogeochemical cycles. Human pressures, direct and indirect, and natural variation in the Earth system, are having significant impacts on these sensitive biological assemblages. These changes can affect fisheries, the distribution and frequency of harmful algal blooms, affect the spatial distribution (range and timing) of different species and cause other shifts in marine habitats around the world. The abundance of many fish species, sea birds, and marine mammals on continental shelves is critically tied to fluctuations in the abundance of smaller planktonic organisms driven by climate-scale changes. On the other hand, changes in the grazing pressure by fish and zooplankton also have a marked 
influence on the diversity, abundance, and productivity of these microorganisms (Prowe et al., 2012). Many of these changes are impossible to detect without an observing system in place, or without an agreement on what to measure and how to make these measurements so that they can be compared from one location to another and over time.

Continuous Plankton Recorder (CPR) surveys exist in several ocean basins, with time series up to multiple decades, providing plankton diversity and distribution information. While not yet truly global, there are efforts underway to expand CPR surveys to other key areas and integrate with other observing systems (Batten et al., 2019). Measuring plankton distribution, biodiversity, abundance, productivity, and changes in these variables over time in the global ocean is impractical without agreement on best practices and strategies for integration with existing time series. GOOS now provides a framework to coordinate global, sustained and multidisciplinary observations of plankton. Under the GOOS, experts from across ocean disciplines have formulated recommendations for a multi-year implementation plan that addresses requirements, observations, data management, and information products for a sustainable plankton observing capability (Lombard et al., 2019).

Persistent challenges include spatial coverage and temporal resolution of plankton observations, observation technologies, and the need for standardized methods or Best Practices (Przeslawski et al., 2019). New automating technologies, such as imaging and 'omics are increasing data collection opportunities, while machine learning processes and improved (real time) quality control will facilitate development of standardized outputs that can be harvested directly by major biodiversity databases such as OBIS and GBIF. At the same time, it will be necessary to carefully document the capabilities of new technologies and methods as complements or replacements for more traditional approaches. Pilot projects to test components of the implementation plan at local to regional scales involving imaging equipment such as the Underwater Vision Profiler (UVP), the Imaging Flow CytoBot (IFCB) or other automated systems on selected GO-SHIP lines or at fixed stations such as OceanSITES will be important in demonstrating the scalability of plankton observations to the global ocean (Miloslavich et al., 2018c).

Improved communication with all ocean stakeholders, including the public, policy makers, environmental managers, and industry, are essential to future development of this EOV. The public needs to understand the importance and impact of changes in plankton communities for the wellbeing of human populations and for ocean health. Sustaining the ecosystem services that plankton provide is crucial for the security of nations.

\section{Fish Abundance and Distribution}

Monitoring the spatial and temporal dynamics of fish is a basic requirement for their assessment under the impacts of climate change, fishing and pollution. Due to their global coverage, most indicators of change are based on commercial fisheries catch data. However, there are significant issues regarding accessibility of fisheries data and obligations of national reporting to the Food and Agricultural Organization of the United Nations (FAO). Multiple lines of evidence show the importance of fisheries independent data to provide reliable assessments of fish status in support of management decisions for an ecosystem approach to fisheries (Shin et al., 2012; Pauly et al., 2013; and see references in Miloslavich et al., 2018a). In addition, the status of many non-commercial fish, marine mammals, sea turtles and seabirds impacted by commercial or recreational fishing, pollution, habitat degradation and climate change, provide important information for ecosystem-based approaches to fisheries management.

Multispecies trawl survey data, pelagic acoustic survey data, tagging data, and underwater survey data are rich sources of information for coastal and offshore fish communities. These data are collected in many countries. In addition, less infrastructure-dependent approaches for coastal and continental shelf sites including citizen scientist diver surveys (Edgar and Stuart-Smith, 2014) and Baited Remote Underwater Video (BRUV, Hill et al., 2018) provide cost-effective approaches to sample shallow water fish communities.

New technologies expanding data collection opportunities are already in use or are under development including e-monitoring on fishing vessels, acoustic echosounders on fish aggregating devices (FADs) or gliders, sound monitoring, and environmental DNA. Midwater acoustic methods are being developed for monitoring the mesopelagic fish community (Proud et al., 2018). However, for most of these methods, spatial and taxonomic coverage remains narrow, and further development is required to automate and standardize the collection and analysis of data.

Unfortunately, data are rarely standardized or accessible. More initiatives are needed to make data open (e.g., Reef Life Survey; Edgar and Stuart-Smith, 2014), coordinated and quality controlled (e.g., DATRAS for trawl surveys in European seas ${ }^{3}$ ) and available for people to store data collected globally (e.g., OBIS or for BRUV data ${ }^{4}$ ). A first step in developing this EOV will be to inventory existing databases (metadata and metadata standards) around the world to identify opportunities and incentives to increase the availability of fisheries independent observations.

Secondly, strengthening the linkages between global and national indicator development and reporting, and demonstrating the utility of this EOV through use cases will support collaboration between multiple stakeholders, including the Convention on Biological Diversity (defining new targets for maintaining exploited ecosystems within safe limits), the Biodiversity Indicators Partnership (highlighting indicators for measuring progress in achieving targets), the UN Fisheries and Agriculture Organisation (leading national reporting), national fisheries departments (conducting primarily exploited fish surveys), national environmental departments (conducting primarily non-exploited fish surveys, including threatened species), scientific experts (through e.g., ICES and PICES working groups, CLIOTOP, INDISEAS), fishing industries, NGOs, and regional fisheries management organizations.

\footnotetext{
${ }^{3}$ http://www.ices.dk/marine-data/data-portals/Pages/DATRAS.aspx

${ }^{4}$ http://www.globalarchive.org
} 


\section{Turtles, Birds, and Mammals}

Turtles, birds, and marine mammals are important components of marine foodwebs, often at the top, and with the potential to exert top down control on foodweb structure and composition (Estes et al., 2014, 2016; Roman et al., 2014; McCauley et al., 2015). They also play a previously unrecognized role in biogeochemical cycling, as their foraging activities transport macro and micro nutrients both horizontally and vertically (Roman et al., 2014; Doughty et al., 2016; Moss, 2017). The habitats of these marine vertebrates whether they are associated with feeding, breeding or migration all depend on climate driven oceanographic features (Briscoe et al., 2017). For example, migration and dispersal of sea turtles is highly correlated with surface currents (Girard et al., 2009; Tew Kai et al., 2009; Peckham et al., 2011) while seabird foraging and migration depend on oceanic wind patterns (Weimerskirch et al., 2000; Suryan et al., 2008; Weimerskirch et al., 2012; Gutowsky et al., 2014). Foraging is most efficient in highly productive regions where primary production is greatest (Tynan, 1998; Croll et al., 2005), or where prey is concentrated due to mesoscale features such as fronts, eddies and filaments (Bost et al., 2009; Hindell et al., 2016; Abrahms et al., 2018). Predictions of climate associated changes in their habitat suggest that there will be winners and losers (Hazen et al., 2013) with some climate driven changes in populations already being observed. (Ducklow et al., 2013; Boersma and Rebstock, 2014; Descamps et al., 2015; Thorne et al., 2016).

As "charismatic megafauna" these organisms have high societal value. Considerable resources go into their conservation and management (Moore et al., 2009; Wallace et al., 2011; Lewison et al., 2013; Borggaard et al., 2017; Lent and Squires, 2017) as well as methods to monitor their populations (Southwell et al., 2012; Battaile and Trites, 2013; Desprez et al., 2013; Hatfield, 2013; Kirkman et al., 2013; Moore and Barlow, 2013). Populations of many of these species have been monitored for decades (Rotella et al., 2012; Pardo et al., 2017; Southwell et al., 2017; Tompkins et al., 2017; Weimerskirch et al., 2018), but many different methods are employed to estimate key variables such as population size, demographic changes, body condition and movement patterns. Very little of the resulting data are compiled in a common repository. Monitoring of these populations also involves solving logistical challenges. For example, Cetaceans are a logistically difficult group to monitor, as they spend their entire lives at sea and to monitor, survey or capture them requires considerable effort. While, the logistics associated with assessing populations, animal condition, movement patterns and diet for colony breeding sea turtles, seabirds, and pinnipeds have been well established, some species and populations may be difficult to access due to their remote location or cryptic nesting habitat such as burrowing seabirds.

Although significant time-series exist for many marine vertebrates, the data have not been collected in a common repository so in most cases they are not accessible while in others even their existence is poorly known. A significant step forward, and a goal for GOOS over the next few years, will be to develop a data portal to identify existing data sets and who manages them, with a goal to eventually provide direct access to the data. This will require bringing together the various communities collecting and using the data to identify or establish best practices for data collection, analyses, maintenance, and archiving. The most successful program pursuing best practices to date has been the CCAMLR Ecosystem Monitoring Program or CEMP (Reid et al., 2005; Constable, 2011). This program developed a series of metrics that can be used to follow the status and condition of species of seabirds and marine mammals that are krill predators. CEMP established a detailed series of metrics that have been used to monitor krill-eating birds and mammals.

Our aim over the next 5 years is to focus on each taxa, identify existing networks collecting data on their abundance and distribution through various methods and engage the communities to refine and agree to best practices as observations are brought together and made available globally.

\section{Hard Coral Cover and Composition}

Coral reefs are under significant direct pressure from human activities in the form of fishing, pollution, recreation, transport and coastal development, and are especially vulnerable to the global threats of ocean warming and acidification (Burke et al., 2011; Hughes et al., 2017). Recent analyses indicate that most coral reefs will not survive the next 3-5 decades unless the most ambitious climate mitigation targets are met (van Hooidonk et al., 2016; Beyer et al., 2018), or they can ecologically adapt. The importance for developing sustained global observing is highlighted by the IPCC report on $1.5^{\circ} \mathrm{C}$ warming, in which the difference between $1.5^{\circ}$ and $2^{\circ} \mathrm{C}$ warming is illustrated by losing nearly all, versus losing all, coral reefs globally by the end of this century (Intergovernmental Panel on Climate Change, 2018).

Given the high vulnerability and value of coral reefs, establishing local to global long-term monitoring of the health and drivers of coral reefs is of paramount importance (GCRMN, 2017; Miloslavich et al., 2018a), and has been a priority of the International Coral Reef Initiative for 20 years or since the 1st global coral bleaching event of 1997-98 (e.g., Wilkinson, 2000, 2008). Recent guidance from both GOOS (Lindstrom et al., 2012) and GEOBON (Pereira et al., 2013) on establishing global observing networks provided key inputs to a redesigned global observing network for coral reefs, in the form of the GCRMN (2018), including an expanding the scope to integrate socioeconomic and biophysical elements. Key redesign elements include: (1) network design applying the principles of the Framework for Ocean Observations (Lindstrom et al., 2012 p. 7); (2) applying the Drivers Pressures Status Impact Responses (DPSIR) model used in many convention processes (Patricio et al., 2016; Miloslavich et al., 2018a); (3) adopting the EOV/EBV frameworks (Muller-Karger et al., 2018b) to identify the priority variables for understanding and reporting on the health of coral reefs; and (4) an integrated monitoring/adaptive management approach to ensure local-level management can respond to pressures, trends and capacity.

A GOOS/GCRMN hard coral cover and composition EOV workshop was held in Dar es Salaam, Tanzania in November 2017 with the support of IOC, the International Coral Reef 
Initiative (ICRI), and UN Environment ${ }^{5}$. A governance plan to strengthen the GCRMN based on the discussions of this workshop and two more workshops organized by the UN Environment was adopted in December 2018 by the International Coral Reef Initiative (GCRMN, 2018).

\section{Seagrass Cover and Composition}

The dominant primary producers on sedimentary shores around the world are seagrasses, which provide habitat structure and food for diverse and abundant animal communities and are hotspots of ecosystem and biogeochemical processes. Seagrass meadows are economically central to coastal human communities, particularly in the developing world, contributing to fisheries yield, storm protection, blue carbon storage, and important cultural values (Nordlund et al., 2016; Unsworth et al., 2018).

Recent assessments of global seagrass status and trends show substantial loss of seagrass over recent decades threatening the services provided by these ecosystems (Waycott et al., 2009; Grech et al., 2012). The principle drivers of change in seagrass cover on a global scale are urban and industrial runoff, urban and port infrastructure development, agricultural runoff, and dredging (Grech et al., 2012). Tracking status and trends in seagrass cover and quality is therefore widely recognized as a priority for coastal management, and seagrass is monitored at numerous sites worldwide.

In 2018, researchers and managers from around the world drafted a consensus assessment and recommendations on the current state of, and opportunities for, advancing global marine macrophyte observations, integrating contributions from a community with broad geographic and disciplinary expertise (Duffy et al., 2019). This review noted that several challenges hinder effective global observing of seagrass status and trends. Central among these is lack of coordination among the numerous seagrass monitoring programs, which in turn is hindered by wide variance in their goals, methodologies, and data availability. A second major challenge is the difficulty of quantifying seagrass cover and distribution with remote sensing as is done routinely for phytoplankton biomass and, increasingly, for coral reef cover.

Based on review of 19 active, multi-site seagrass monitoring programs and many more local efforts, the consensus assessment made several main recommendations: a coordinated seagrass observing system will best be built by: (1) harmonizing observations and best practices developed by existing networks; (2) identifying a core set of common metrics and a common hierarchical sampling design; (3) actively promoting common standards for taxonomy, data management, and governance; and (4) active capacity building. The group also recognized strong potential for advancing coordinated observations of seagrass ecosystems by more closely integrating existing in situ surveys with remote sensing imagery and incorporating environmental DNA and metagenomic approaches for sampling taxa difficult to assess by traditional sampling. Realizing these recommendations will produce more effective, efficient, and responsive observing,

\footnotetext{
${ }^{5}$ Summary and recommendations at: http://www.goosocean.org/index.php? option=com_oe\&task=viewDocumentRecord\&docID=20794.
}

a more accurate global picture of change in seagrass systems, and stronger international capacity for sustaining observations. The consensus among global seagrass researchers indicates that the community is engaged and committed to moving these goals forward. These efforts are continuing through an ongoing assessment led by the International Seagrass Experts Network and UNEP/GRID-Arendal.

\section{Macroalgal Canopy Cover and Composition}

Macroalgal forests are iconic on rocky shores around the world's coasts. These highly productive and diverse ecosystems provide many important functions and services including provision of nursery areas, human food resources, and protection from coastal erosion. Macroalgal forests and the associated assemblages are vulnerable to global threats such as ocean warming and acidification, and to regional anthropogenically mediated stressors including habitat degradation, eutrophication, other pollution, over-fishing, and invasive species. Due to their sensitivity to a variety of stressors, macroalgal forests are indicators of the status and trends of marine coastal ecosystems worldwide.

To develop a global, coordinated strategy for monitoring macroalgal forests, the Partnership for the Observation of the Global Ocean (POGO) supported a Working Group (WG) of international, multidisciplinary experts to plan the implementation of a standardized, innovative and cost-effective monitoring system. The WG compiled metadata of more than 80 existing programs operating from local to global scales, identifying the strengths of these efforts in addition to the gaps and requirements to achieve global standardization. The WG also reviewed the methods available to monitor macroalgal forests, including visual census, acoustics, laser imaging, remote sensing from satellites, molecular tools (including environmental DNA), and imagery (stills, automated/remote vehicles, drones). The strength and weaknesses of the different methodologies were evaluated and compared with respect to feasibility, training requirements, spatial scale of analysis and taxonomic resolution. A fit-for-purpose Standard Operating Procedure (SOP) is being drafted for each of the different methodological approaches. The requirements for data integration, assimilation and dissemination were discussed and a data management architecture was proposed to provide a centralized repository linked with OBIS under the principles of "Findable, Accessible, Interoperable, and Re-useable" (FAIR) data.

Persistent limitations hampering the implementation of a global monitoring network for macroalgal forests include the harmonization of data originated by different technologies, the adoption of common protocols and the use of standardized vocabularies. Sampling designs should reflect clearly stated questions and hypotheses about the drivers of change in macroalgal forests at local, regional and global scales. Clarification of the relevant questions beforehand will facilitate the adoption of common designs and data integration, also allowing more powerful analyses. Adequate resources need to be made available to guarantee the long-term commitment of a global network. 
The POGO-supported working group defined a strategic implementation plan to address these challenges and to promote macroalgal canopy cover and composition as an EOV, including: (1) formalize a data request template and data sharing agreement to compile a comprehensive inventory of existing datasets; (2) finalize the SOPs for the different methodological approaches to be made available through the Ocean Best Practices platform; (3) develop vocabularies, non-taxonomic categories and units for recorded variables; and (4) improve communication and dissemination through papers, presentations, training material and websites. The vision is to integrate macroalgal canopy cover and composition into a global observing network and to promote this EOV as a leading indicator of the status and trends of macroalgal forests worldwide.

\section{Mangrove Cover}

Found in the coastal zones across the tropics, subtropics and temperate regions, mangroves are forested wetlands that are uniquely adapted to the intertidal zone. Although mangroves provide many critical resources to local populations, including food and timber, their extent has been reduced over recent decades, and many habitats have been fragmented or degraded (FAO, 2008; Romanach et al., 2018). Changes in the distribution of mangroves have gone largely unrecorded and many areas have been permanently or temporarily lost primarily due to human activities. The lack of monitoring and assessment at country, regional and global scales has often led to losses not being recognized, while impacts of losses on the integrity of ecosystems have rarely been quantified. However, increasing efforts are now being made to both protect and restore mangroves. A fundamental requirement for mangrove protection and restoration is to understand current and historical mangrove distributions and condition (Bunting et al., 2018).

Sustained measurements of mangrove cover and composition are necessary to assess the state and change of these ecosystems, address scientific and societal questions and needs, leading to information to help mitigate pressures on mangroves at local, regional and global scales. While various platforms exist, few provide consistent and sustained observations of both mangrove cover and composition beyond the national scale. The scientific community has been active in both addressing the gaps in information on global mangrove cover and in identifying opportunities for restoration. Through the Global Mangrove Watch, an international project set up to provide geospatial information about mangrove extent and changes, a time-series of maps of the global mangrove extent was generated and released in 2018. Including a baseline showing the global extent of mangroves in 2010, maps are currently available for seven annual epochs including 1996, 2007, 2008, 2009, 2015, and 2016 from which losses and gains in any location can be assessed (Bunting et al., 2018). These data provide the information needed to report at the national level on mangrove extent to the Ramsar Convention and the Sustainable Development Goals (6 and 14 in particular), as well as Nationally Determined Contributions under the Paris Agreement and the UN Reducing Emissions from Deforestation and forest Degradation scheme (REDD+) under the UN Framework Convention on Climate Change (UNFCCC).
The Global Mangrove Alliance is working to develop a mangrove monitoring system to track progress toward their restoration target of $20 \%$ of mangroves globally by 2030 .

While these platforms address the previous information gap on mangrove extent, data are still lacking on mangrove species distribution and habitat type. Determining the characteristics and composition of mangroves requires more detailed site level information. In some locations this information is provided through national mangrove monitoring systems (e.g., Mexico and Australia), but the existence of national level systems is often constrained by financial and staff resources and they are not common globally. Even in Australia it took over 6 months before the loss of over $1,000 \mathrm{~km}$ of mangroves was noticed by scientists or authorities (Duke et al., 2017).

An inventory of existing databases will be the first step in identifying best approaches for addressing EOV requirements. The implementation plan for this EOV will include: (1) assessing the maturity of measurements; (2) coordinating observations; and (3) identifying appropriate data standards and management approaches. A workshop is scheduled in June 2019 to develop the mangrove (and seagrass) EOVs.

\section{Microbial Biomass and Biodiversity}

The ocean microbiome plays a central role in the state and functioning of the entire marine realm, its biogeochemical cycles, and the health of its flora and fauna (Moran, 2015; Hutchins et al., 2017). Consequently, the marine microbiome rapidly responds to natural and anthropogenic pressures, offering a rich source of largely untapped bioindicators of phenomena including invasive species, the presence of pathogens and environmental contaminants, and ecosystem resilience [see Buttigieg et al. (2018) and Bourlat et al. (2013), for commentary). As global capacity and drive to monitor environmental microbiomes grow (Dubilier et al., 2015; Goodwin et al., 2017; Thompson et al., 2017), the GOOS BioEco panel has recognized the need to develop an EOV reporting on microbial biomass and diversity in the oceans. Microbial life constitutes a notable proportion of Earth's total biomass, particularly in the form of bacterial biomass in the subsurface (including subseafloor sediments and the oceanic crust) (Kallmeyer et al., 2012; Bar-On et al., 2018). Monitoring microbial biomass is key to understanding the biogeochemical dynamics of ecosystem-defining events such as cyanobacterial blooms, their remineralization, and associated oxygen consumption during material export to the deep. The second component of this EOV addresses the immense and deeply minable functional and phylogenetic diversity of microbial assemblages. Rapidly advancing and increasingly affordable molecular profiling technologies, remote sampling solutions, and ecogenomic sensors (McQuillan and Robidart, 2017; Scholin et al., 2017) have greatly increased the feasibility of routinely assessing microbial biodiversity and have been refined over a decade of large-scale marine sampling campaigns (e.g., Rusch et al., 2007; Kopf et al., 2015; Sunagawa et al., 2015; Biller et al., 2018). These factors, bolstered by experience from methodological intercomparisons (e.g., Pesant et al., 2017; Sczyrba et al., 2017), are increasing the deployability of "omics" technologies within global frameworks of biodiversity and ocean 
assessment (Bruford et al., 2017; Buttigieg et al., 2018; for more on omics in biodiversity monitoring, consult Canonico et al., this issue). Harmonization and standards are increasingly necessary to achieve large scale analysis of the increasing data volumes being generated from "omics" technologies.

In consultation with a growing group of experts, we are working toward the first release of the Microbial Biomass and Biodiversity EOV's GOOS specification sheet. The initial scoping of the EOV will focus on bacterial and archaeal life; however, the viral and eukaryotic components of the microbiome will also be considered as our expert group grows. Microbial observatories federated through thematic networks such as the Global Omics Observatory Network (GLOMICON) ${ }^{6}$ and the Genomic Observatories (GOs) Network (Davies et al., 2014) will be instrumental in this endeavor, as will information infrastructures such as the International Nucleotide Sequence Database Collaboration (INSDC), GBIF $(2018)^{7}$, and OBIS $^{8}$. Multiple workshops over 2018 and 2019 have connected these entities to the Microbial EOV, as well as the IOC-UNESCO Ocean Best Practice System (OPBS; Pearlman et al., this issue) ${ }^{9}$ and the Genomic Standards Consortium (GSC) ${ }^{10}$. The conclusion of the 21st meeting of the GSC (May 2019; Vienna) has resulted in the strategic alignment of GLOMICON and the GOs Network around the production of data products such as this EOV, significantly enhancing its prospects for advancement over the next three to 5 years.

There are several key challenges in the mainstreaming of microbial observation. On a conceptual level, we recognize that this EOV must be disaggregated as the scale of the "microbial" world spans several orders of magnitude. Eukaryotic, archaeal, bacterial, and viral sub-variables must be defined, each one led by domain experts nested within the core EOV. Further, the overlap and complementarity of this EOV - in theory and practice - with the Phyto- and Zooplankton EOVs must be carefully considered, likely leading to overlapping data products and communities of practice. Next, the considerable challenge of harmonizing and operationalizing global practices and promoting data sharing in a quickly developing and competitive field will require a great deal of coordination and meaningful incentivization to ensure interoperability from field sampling to data product creation. Anticipating ever-increasing technological capacity, long-term sample archiving to support decadal re-sequencing and analysis must be concretized through organizations such as the Global Genome Biodiversity Network $(\mathrm{GGBN})^{11}$. As a corollary of sampling valuable biomaterial, microbial observers must also address the challenge of navigating and complying with international biodiversity legislation such as the Nagoya Protocol and the emerging legal agreements on biodiversity of the high seas under the UN Convention on the Law of the Sea. Lastly, sustainable resourcing of the practices chosen to measure this

\footnotetext{
${ }^{6} \mathrm{http} / / /$ www.glomicon.org

${ }^{7}$ http://www.gbif.org

${ }^{8}$ https://obis.org/

${ }^{9} \mathrm{http}: / /$ www.oceanbestpractices.org

${ }^{10} \mathrm{http}: / /$ gensc.org

${ }^{11} \mathrm{http}: / /$ www.ggbn.org
}

EOV (which may vary from local methods) must be secured by multiple partners in variable funding environments and bolstered by capacity sharing strategies (e.g., regional or project-based sequencing, regional sample archiving) where appropriate.

While the challenges are formidable, they are far outweighed by the great opportunity of augmenting biological observation with microbial insight. In addition to the integration and implementation common to other EOVs, we recommend: the development and use of physical calibration standards (e.g., "mock communities") and reference samples to enhance comparability between laboratories; the systematic development and testing of novel microbial bioindicators for ecosystem state and health, and; engaging with sensor and sampling hardware developers to ensure mutual alignment with EOV specifications.

\section{Supporting EOVs (Additional to Existing Physical and Biogeochemical EOVs) Ocean Sound}

Sound propagates so well in the ocean that it is the most effective way to probe the marine environment and communicate over long distances. Sound is critical for marine life and for seagoing humans. Many marine animals produce sound and acoustic cues are essential for larvae to settle in appropriate environments, for the mating systems of many fish and mammals, for predator-prey relationships, and for social species to maintain cohesion. Most fish and invertebrates sense sound-induced particle movement; some fish and all mammals detect changes in sound pressure, and the primary variables for Ocean Sound are time series of these two components of sound. However, the primary uses of the Ocean Sound EOV are biological and ecological.

The Ocean Sound EOV will forge major advances in our understanding of how acoustic monitoring can be used to assess biodiversity and ecosystem health, how different sources of anthropogenic sound affect ocean ambient (or background sound), and the effects sound has on marine life. We know that anthropogenic noise can harm marine life in the short term, but more extended observations are required to define longterm effects on populations and ecosystems. Understanding the potential for ocean noise as a stressor requires (1) estimating how ocean sound has changed historically, (2) mapping sound throughout the oceans on a global scale over decades, and (3) predicting sound fields that result from changes in the use of the oceans. Impacts will be taxa-specific.

The Ocean Sound EOV will be implemented under auspices of International Quiet Ocean Experiment (IQOE) which is under governance from SCOR (Scientific Committee on Oceanic Research) and POGO (Partnership for Observation of Global Oceans). The specification sheet for Ocean Sound was drafted in 2016-2017 by an IQOE Working Group funded by POGO and revised in response to review by the GOOS BioEco panel during the fall of 2017 and spring of 2018. It was approved by GOOS during the summer of 2018. The Ocean Sound EOV has been presented to scientific stakeholders at the Joint American and European Societies for Acoustics in Boston June 2017. Engagement with non-scientific stakeholders included the Comprehensive Test Ban Treaty Organisation, International 
Maritime Organisation among international organisations, and US agencies including the NOAA Ocean Noise Strategy Group, US Office of Naval Research, and Bureau of Ocean Energy Management. Presentations were given at the World Ocean Council in Halifax, Nova Scotia, Canada, November 2017, at the United Nations Open-ended Informal Consultative Process on Oceans and the Law of the Sea in New York, June 2018, and the US Sub-committee on Ocean Science and Technology (SOST) known as the "Ocean Noise and Marine Life Task Force" in Washington DC, August 2018. Future efforts to develop the implementation plan include emailing the EOV spec sheet for review and input, a workshop scheduled for spring 2019 and a session before or after OceanObs'19.

\section{Marine Debris}

Marine debris is both widespread in the marine environment (Eriksen et al., 2014) and has significant ecological, social and economic impacts. Plastics form a large and enduring proportion of marine debris, and many governments and communities throughout the world are implementing policies to reduce the amount of plastics entering the marine environment. Plastics also degrade extremely slowly in the open ocean leading to local accumulations and the passage of plastics to the deepest parts of the world ocean. Despite increasing attention in recent years, the impact of plastic litter in the oceans remains uncertain and remains a key objective of the Group of Experts on the Scientific Aspects of Marine Environmental Pollution (GESAMP) Working Group \#40 12 .

This working group is developing guidelines for sampling and analysing marine macro-plastics and microplastics, including: defining the size and shape of particles; sampling protocols for surface and sub-surface seawater, seabed sediments, shorelines and biota; and, physical and chemical identification and analysis of polymers and associated chemicals requirements for monitoring and assessment. The GOOS Biology and Ecosystems Panel will be collaborating with this working group to support the development and uptake of these guidelines.

\section{Ocean Color}

The term "ocean color" broadly refers to the spectral radiance emanating from the sun that is backscattered off the upper part of the oceanic water column, and which contains information on the properties of the water and its constituents. The phenomenon of color is the result of absorption and scattering, as light interacts with the water and materials suspended or dissolved within it (i.e., the optically active "constituents"). Ocean color encompasses a multitude of biological, biogeochemical, and ecological properties of the ocean, and is an EOV and ECV because changes in the color of the ocean can be related to changes in the presence and magnitude of living and non-living particles and of dissolved materials in the water. Ocean color can be used to discriminate different water bodies, evaluate the health of marine ecosystems, and inform resource management, e.g., aquaculture, fisheries and recreation and provides an example of how other biological EOVs might be implemented.

\footnotetext{
${ }^{12}$ http://www.gesamp.org/work/groups/40
}

Measurements of ocean color include the intensity and spectral variability of light backscattered from below the ocean surface, vertical profiles of the color of water, and measures of inherent optical properties like the absorption or scattering coefficient. Current methods to observe the ocean's optical properties include underwater optical sensors as well as airborne and satellite observations. Sustained ocean color remote sensing observations are obtained routinely from polar-orbiting and geostationary satellites, AERONET-OC stations, and airborne sensors. Ships, buoys, and automated platforms, including gliders, Argo floats, and other various specialized sensors deployed at various sites, including validation sites, provide complementary in-water optical observations which are used to calibrate on-orbit satellite sensors and validate remotely sensed data products.

To fully use the ocean's optical properties for ocean science, it is critical to understand the properties of different water types, and the limitations and possible errors in derived "ocean color products." Products include phytoplankton chlorophyll a concentration, biogeochemical and ecological indices including water quality measures, metrics to gauge phytoplankton physiology, and indicators of ecosystem status and health. Environmental variables such as bathymetry, dissolved organic carbon, and suspended sediment concentration can be derived and will often need to be accounted for before biological components can be estimated. In situ sampling is required to validate remotely sensed products.

To date, ocean color sensors have focused on measuring in the visible spectrum of light including PAR (Photosynthetically Available Radiation, or between 400 and $700 \mathrm{~nm}$ ). However, there is a clear need for ocean color sensors to observe from the ultraviolet (UV) to the short-wave infrared (SWIR), with high spectral resolution (hyperspectral), and with more sensitive sensors (signal to noise) to enable more precise atmospheric correction over turbid waters, as well as to enable development of new products and revision of existing products, including suspended and dissolved matter in turbid waters, bathymetry, plankton functional types, and other products. Applications in coastal and inland waters require higher spatial resolution (i.e., pixels of order of meters to tens of meters) than open ocean assessments (spatial resolution of hundreds of meters to kilometers).

\section{Links to Other Essential Variable Initiatives}

No one group has the imprimatur to identify a set of oceanographic variables that all other researchers would be expected to measure and record. Improving general acceptance of Essential Variable initiatives requires demonstrating that there is value in this process, e.g., through the improved interpretation of individual project data, or improved impact of data when it is aggregated and assessed more broadly for science or decisionmaking. It is important in this regard that Essential Variable initiatives collaborate to provide a clear and consistent message to the scientific community. The Essential Climate Variables (ECVs) started in this way in the 1990's and now provide fundamental information to inform negotiations under the United Nations 
Framework Convention on Climate Change (UNFCCC) and the Intergovernmental Panel on Climate Change (IPCC).

The three main groups that the Biology and Ecosystems Panel engages with are: Global Climate Observing System (GCOS), the Marine Biodiversity Observation Network (MBON) and the Ocean Biogeographic Information System (OBIS). Many other groups are accessed through these three groups including the joint representation of individuals on different groups (Muller-Karger et al., 2018b).

\section{Essential Climate Variables}

The Global Climate Observing System (GCOS) has addressed climate-related needs for observations and information since 1992, under the umbrella of four major intergovernmental organizations ${ }^{13}$. GCOS operates through three panels focussed on atmospheric, ocean, and terrestrial observations. The agreed Essential Climate Variables (ECVs) are relevant to the requirements of the UNFCCC and other stakeholders. The new GCOS Implementation Plan (World Meteorological Organization [WMO], 2016) has a focus on closing the climate cycles - Hydrological, Carbon and Cryosphere - by ensuring global observations for adaptation, mitigation and climate indicators. This new plan also considers for the first time biological ECVs related to ocean observations and proposes a series of actions to improve their data delivery (Table 2). The GOOS Biology and Ecosystems Panel worked with GCOS to identify biological ocean ECVs based on the EOVs which in this first iteration are Plankton including both phyto and zooplankton, and Marine Habitat Properties which includes coral reefs, seagrass beds, mangrove forests and macroalgal canopies (Table 2).

${ }^{13}$ https://public.wmo.int/en/programmes/global-climate-observing-system

TABLE 2 | Main actions proposed by the GCOS Implementation Plan in relation to the biological ocean ECVs (World Meteorological Organization [WMO], 2016).

\begin{tabular}{ll}
\hline ECV & Actions \\
\hline Phytoplankton & Improve the conversion of satellite \\
& observations to phytoplankton biomass; \\
implement in situ monitoring along with & other relevant physical and biogeochemical \\
& variables \\
& Implement global CPR surveys expanding \\
& to new areas (e.g., tropical and subtropical); \\
Zooplankton & integrate data \\
& Strengthen existing network of coral reef \\
Coral reefs & of other relevant physical, biogeochemical, \\
& biological and ecological measurements; \\
& encourage the use of inter-calibrated \\
& protocols and implementing capacity \\
& development
\end{tabular}

Mangrove forests, seagrass beds and macroalgal communities

\section{Essential Biological Variables}

Essential Biodiversity Variables (EBVs) were defined by the Group on Earth Observations (Pereira et al., 2013) and are complementary to the biological EOVs developed by GOOS. While the biological EOVs are strictly organized around species and habitats, the EBVs also include biological processes. Some EBVs are consistent with supporting variables under the EOVs, while some EOVs are examples under an EBV class. While there is not a one to one relationship or strict hierarchy linking the biological EOVs and EBVs, they will often be monitoring the same aspects of the marine environment.

The Marine Biodiversity Observation Network (MBON), a thematic component of GEO BON, is collaborating with GOOS, the Ocean Biogeographic Information System (OBIS), and the Integrated Marine Biosphere Research (IMBeR) project to ensure that EBVs and EOVs are complementary, representing alternative uses of a common set of scientific measurements (Muller-Karger et al., 2018b).

Characterizing biodiversity and understanding its drivers will require incorporating observations from traditional and molecular taxonomy, animal tagging and tracking efforts, ocean biogeochemistry, and ocean observatory initiatives including the deep ocean and seafloor. The partnership between large-scale ocean observing and product distribution initiatives (MBON, OBIS, JCOMM, and GOOS) is an expedited, effective way to support international policy-level assessments (e.g., the Intergovernmental Science-Policy Platform on Biodiversity and Ecosystem Services or IPBES), along with the implementation of international development goals (e.g., the United Nations Sustainable Development Goals).

\section{Ocean Biogeographic Information System}

OBIS is a global open-access data and information clearinghouse on marine biodiversity for science, conservation and sustainable development. For almost 20 years now, OBIS and its 30 regional OBIS nodes have been successful in mobilizing a global network of nearly 1,000 institutions to provide seamless, integrated access to nearly 60 million records of 120,000 marine species. Since 2017, OBIS expanded from focussing purely on species occurrence data to embrace datasets that combine biological and environmental data, including details about sampling effort and methods, and supporting EOVs, EBvs and ECVs (De Pooter et al., 2017; Benson et al., 2018). Its new infrastructure (OBIS 2.0) supports robust near real-time data integration and curation and provides powerful data access and analytical services.

A major challenge is that many biological EOV data are fragmented, lack standardization, are not archived, and many remain unavailable. Consequently, very few monitoring networks are currently capable of developing global indicators to feed into policy frameworks, excepting the Continuous Plankton Recorder, which provides indicators for the EU Marine Strategy Framework Directive. Alignment with DarwinCore standards and feeding EOV data into OBIS is a goal for each EOV. Tracking networks which are developing data and metadata guidelines together with OBIS and the Bio-logging Society Good is one example of progress. 
By applying Darwin Core standards to the EOV data (more specifically the Event Core and Measurement or Fact), OBIS will be able to support GOOS in mapping and monitoring the marine biological observing networks globally.

\section{ORGANIZATIONAL STRUCTURE AND CHALLENGES}

The GOOS Biology and Ecosystems Panel reports to the GOOS Scientific Steering Committee, which reports to the Intergovernmental Oceanographic Commission of UNESCO (IOC) Assembly and other sponsors. GOOS was established in 1991 by IOC Member States, with the World Meteorological Organization, UN Environment, and the International Science Council later joining as sponsors.

The Framework for Ocean Observing (Lindstrom et al., 2012) developed from OceanObs'09 recommended establishing two new GOOS Panels - Biogeochemistry, and Biology and Ecosystems - to complement the existing Physics and Climate Panel. This recommendation was endorsed by IOC in 2012. However, endorsement did not result in increased IOC budgetary support. While the Physics Panel is cosponsored by the Ocean Observations Panel for Climate and the Biogeochemistry Panel builds on the International Ocean Carbon Coordination Project, there was no similar global monitoring group for the Biology and Ecosystems Panel to build on, and it has been primarily supported by short-term research grants from individual research agencies in Australia and the United States.

At the same time, GOOS is not the only group interested in monitoring ocean biota. GOOS is in communication with other groups including $\mathrm{MBON}$, the Southern Ocean Observing System (SOOS) and Integrated Marine Biosphere Research [IMBER; including the Climate Impacts on Ocean Top Predators (CLIOTOP) and Integrating Climate and Ecosystem Data (ICED) programs), while groups likely to use the data for further processing include GEO BluePlanet, World Ocean Council, GODAE OceanView. Engagement with FAO, Regional Fishery Management Organizations (RFMO), UN Regional Seas Programs, the International Council for the Exploration of the Sea (ICES), the Pacific ICES (PICES) needs to be expanded. Many, if not all, of these groups are underfunded and rely heavily on voluntary commitments. There is an ever-increasing need for a global inclusive architecture that can support the needs of all these groups.

The other dimension of GOOS is the 13 GOOS Regional Alliances (GRAs) that enable regional cooperation in ocean observing and in some cases in ocean forecasting and services. However, biological monitoring is not included in some GRAs and there is generally a lack of capacity in the developing world. Building an operational system that is truly global requires expanding participation to include a far broader representation of developing and less-resourced countries. Current capacity development activities are insufficient. New stronger partnerships, new funding models, innovative technologies and new training approaches will be required
(Miloslavich et al., 2018b). Linking capacity development to sustained monitoring may be one way to provide long-term effectiveness for both (Bax et al., 2018).

Continuing funding of the GOOS Biology and Ecosystems Panel remains a challenge. The first 3 years of the Panel have had clear scientific aims and outputs, requiring intellectual rather than more tangible investment. Scientific individuals and institutions have the capacity and interest in contributing to endeavors such as GOOS with clear timely deliverables including scientific publications and profile. It may be harder to maintain investment for the longer-term support and coordination of a sustained observing system, especially for research agencies and universities, despite there being so many international frameworks and conventions that would profit from the resulting increased information (Figure 3).

There are high expectations for IOC, given its position as the only UN agency with a mandated role for ocean science, and its role in defining capacity development and technology transfer requirements. These expectations have been raised for example at the negotiations under the UN Convention of the Law of the Sea over a new instrument for the conservation and sustainable use of marine biodiversity beyond national jurisdiction, but the IOC will need to identify additional stable funding opportunities if it is to reach its potential, increase collaboration with other relevant organisations, and support its programs including GOOS.

The development and implementation of a global ocean observing system that incorporates biological essential ocean variables is an explicit objective of the UN Decade. A sustained observing system would specifically contribute to several of the Decade's objectives by: (1) supporting an inventory of ocean resources to enhance their sustainable use; (2) expanding data gathering and data management to help forecasting of ocean food productivity; (3) improving baselines of environmental conditions of coastal ecosystems; (4) increasing scientific knowledge about the impacts of ocean warming, acidification and habitat destruction; and (5) promoting integrated observations and data sharing that are achievable and feed into GOOS.

However, one of the main governance impediments to the development of a global ocean observing system may be the lack of a clear reporting structure. As Banks (2018) stated while reviewing the lack of success of Evidence Based Decision Making since its inception 20 years ago:

\footnotetext{
"But the main obstacle to using evidence in policy development is not so much lack of (potential) supply as lack of demand. Remedying this will necessitate in-depth consideration of governance and other arrangements that shape incentives and the relationship between ministers, advisers and departments." (Banks, 2018)
}

There is clear relevance of the information developed from monitoring the EOVs at national, regional and international level (Figure 4), but without improved governance arrangements there may be few incentives to coordinate and improve delivery of scientific information to decision makers, and little incentive 


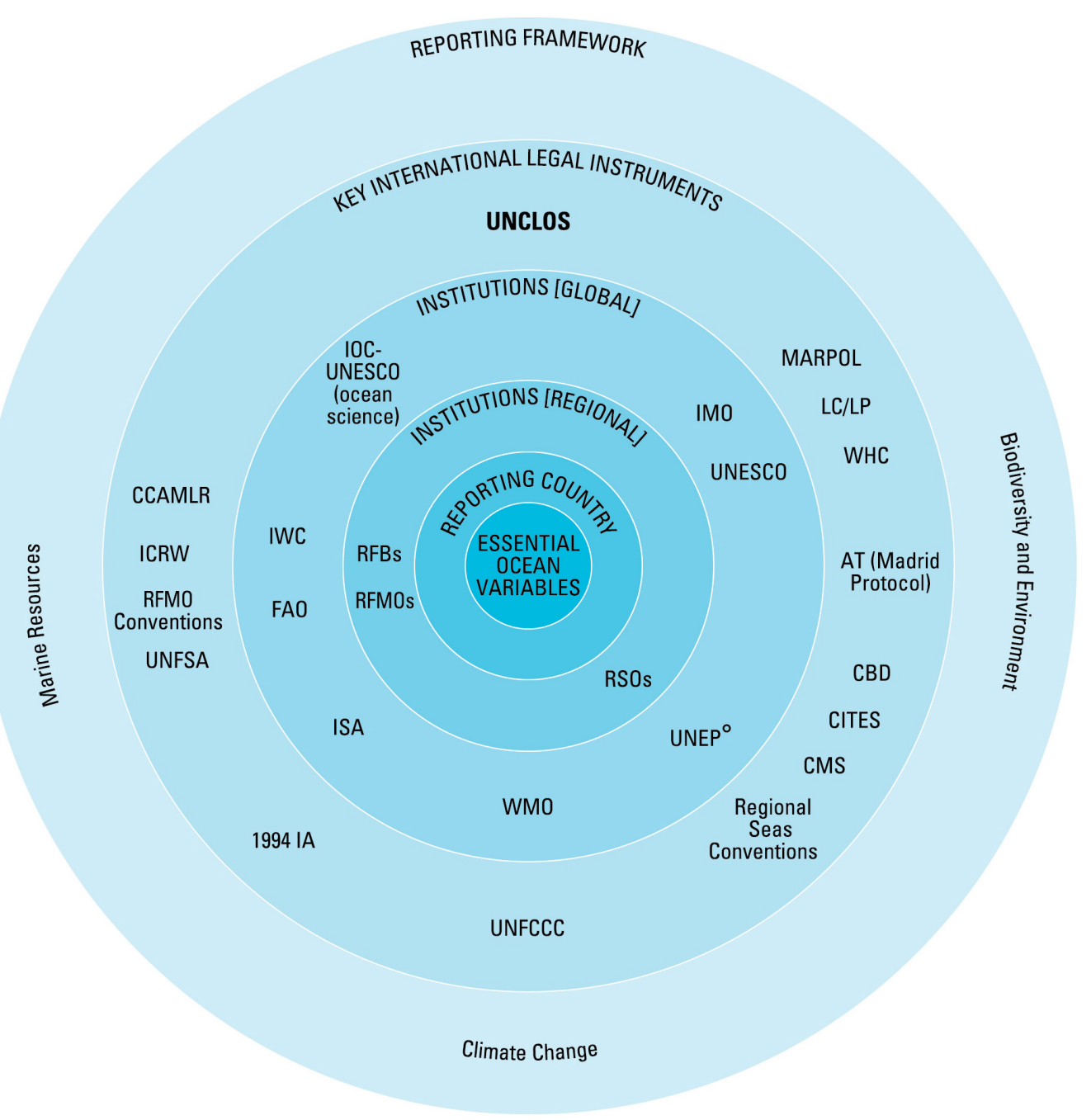

${ }^{\circ}$ includes CBD, CITES, CMS, UNFCCC secretariats
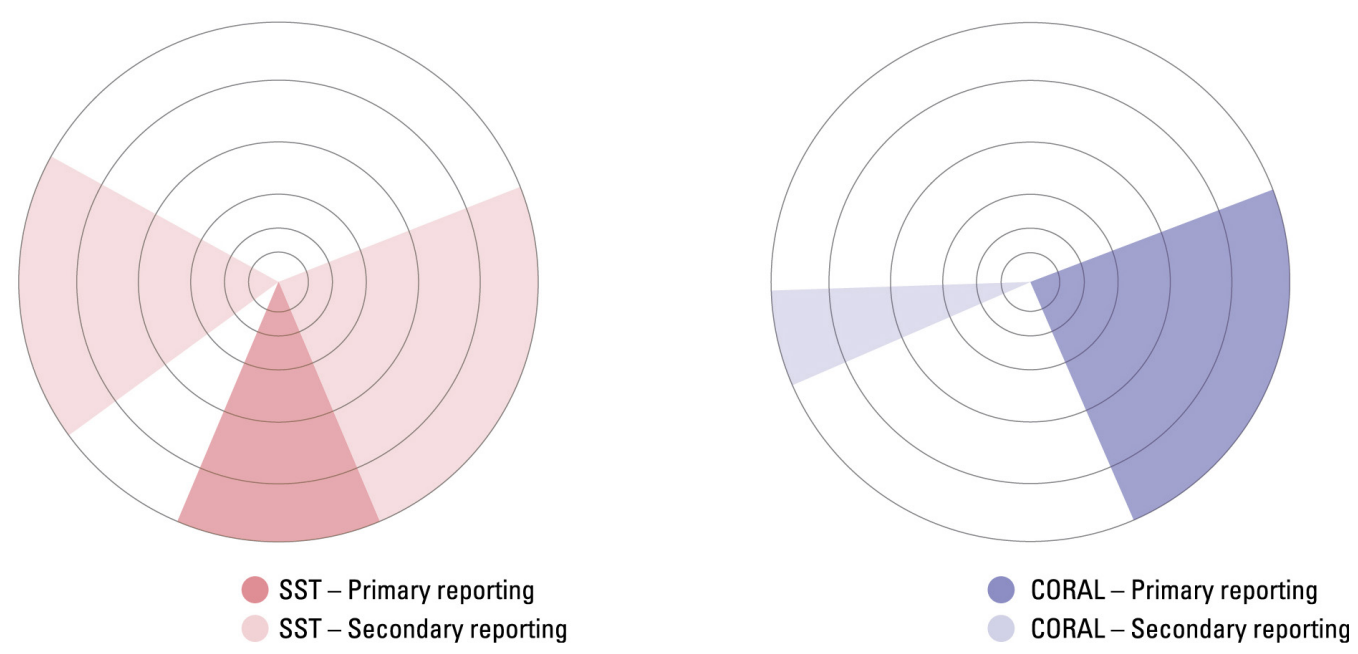

FIGURE 4 | An illustration of the many international instruments, legal instruments, and reporting frameworks that the GOOS EOVs deliver to. The smaller plots indicate the primary and secondary delivery areas for the sea surface temperature and coral cover and health EOVs (from Bax et al., 2018). 
for researchers to modify current project-level priorities to contribute globally.

\section{FUTURE DIRECTIONS AND DEVELOPMENTS}

The advent of a recently expanded set of EOVs, including those focussed on biology and ecosystems coincides with important technological developments in areas of remote and automated data collection, automated image analysis, open data, data management systems, web mapping services, and biodiversity prediction modeling to name a few. Bringing these developments together in a focussed way can provide invaluable data and mapping products useful for research, marine spatial planning, policy development, and environmental regulation (Figure 5).

There are many exciting technologies under development that lend themselves to routine, operational monitoring of marine populations and habitats, including improved platforms, sensors, data analysis and processing. For example, passive acoustics has been used to monitor the presence and movement patterns of species that vocalize (Hildebrand et al., 2015; MacIntyre et al., 2015; Širovic et al., 2015; Munger et al., 2016; Kusel et al., 2017). Satellite images have been used to locate seabird and seal colonies and assess their population numbers (LaRue et al., 2011; Trathan et al., 2011; Fretwell et al., 2012, 2014, 2015, 2017; LaRue et al., 2017), whales at sea (Cubaynes et al., 2018), plankton functional groups and structured benthic habitats (Muller-Karger et al., 2018a). Small easily deployed drones or unmanned aerial systems have been used to assess populations as well as provide estates of body size and condition of marine vertebrates (Goebel et al., 2015; Christiansen et al., 2016; Krause et al., 2017), and may provide an intermediate step in linking satellite data to in situ verification for mapping coastal habitats including mangroves and seagrass.
Under the water, autonomous underwater vehicles (AUVs) can now fulfill a monitoring role that previously required ship time and their capacity to include additional sensors and improve energy management are only going to increase (Hill et al., 2014; Monk et al., 2018). Meanwhile as costs drop, the feasibility of deploying multiple or even fleets of AUVs of different size will increase steadily. Finally, electronic tags are a mature technology that is being used to track the movement patterns, fisheries interactions, habitat utilization and distribution of marine organisms on a global scale (Costa et al., 2010; Block et al., 2011; Costa et al., 2012; Hussey et al., 2015; Brodie et al., 2018; Harrison et al., 2018; Sequeira et al., 2018; Harcourt et al., 2019). Furthermore, electronic tags carried by marine vertebrates have proven to be an extremely effective method for collecting high resolution oceanographic data such as temperature, salinity, and chlorophyll profiles in regions that are difficult, if not impossible (under polar ice) to sample, with other means (see Roquet et al., 2014; Treasure et al., 2017; Harcourt et al., 2019).

New platforms and sensors are leading to a massive increase in samples, including imagery, which will require automated processing to turn into useable data (Figure 5). Automated image processing for marine organisms ranging in size from the smallest plankton to larger vertebrates has been developing over at least the last 30 years but it remains a challenging area. Some areas, for example recognition of plankton, are sufficiently mature that sensors are now commercially available for field use (Boss et al., 2018), while areas like habitat assessment, e.g., of coral reef habitat, are developing rapidly (Roelfsema et al., 2018) and are limited in some cases by human consistency in habitat classification. Other areas such as recognition of fish species in a non-controlled environment, such as might be found during retrieval of a long-line, are proving more challenging. In each of these cases, the automation of easily and relatively cheaply collected image data has the potential

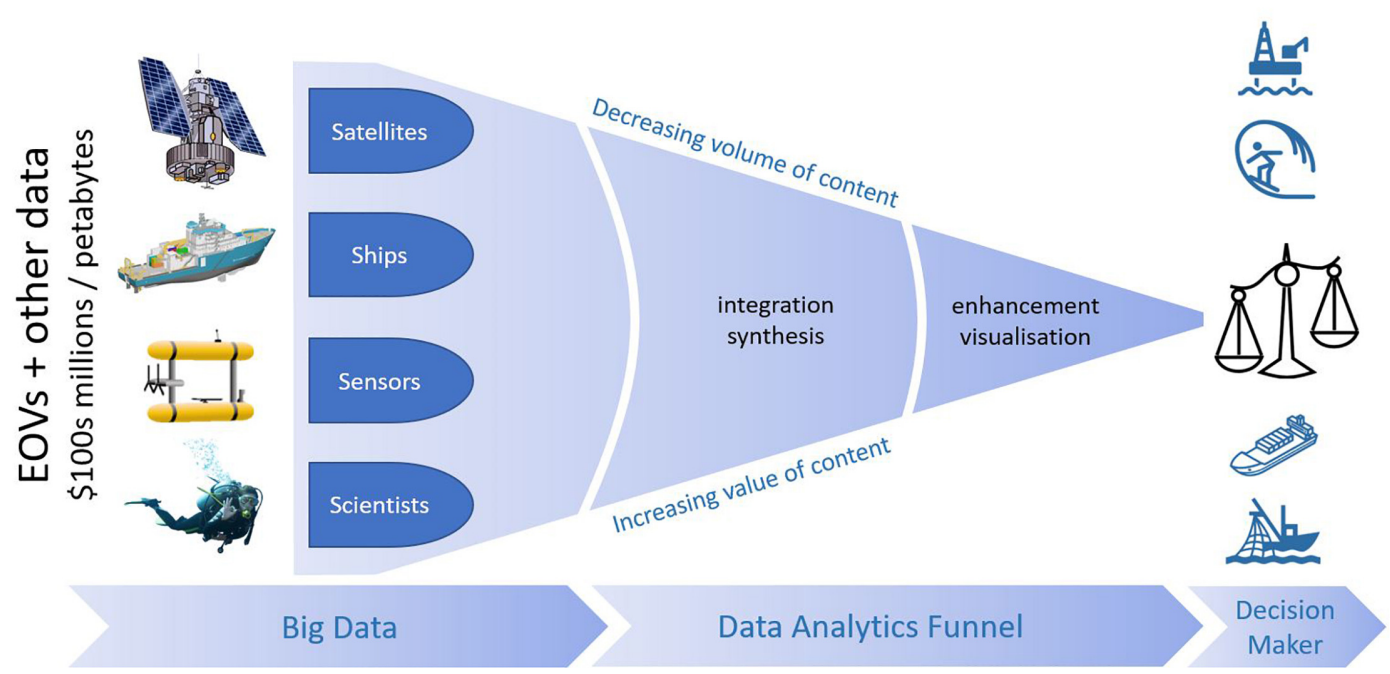

FIGURE 5 | Schematic of "data funnel" able to synthesize EOVs and other large data holdings in a form readily usable by decision makers and scientists. While the endpoint is "data products at finger tips," this kind of system needs to make the underlying data readily findable and accessible from the data product. Seamap Australia is an example of this kind of technology (Butler et al., 2017; http://seamapaustralia.org). 
to revolutionize the amount of data collected and information provided to scientists and decision makers. This will extend the observations collected on existing sampling platforms, provide new options for building capacity in developing countries, and improve monitoring globally.

Advances in multi-omic sequencing technology and practice have allowed access to the biodiversity of entire communities, including many microbes which resist cultivation in the laboratory. Among these technologies, the targeted sequencing of phylogenetic marker genes and the mass sequencing of a community's entire genomic content (metagenomic) are currently the most feasible targets. Measures of functional and phylogenetic diversity provide unprecedented insight in to how microbial assemblages both respond to and shape ocean dynamics (Buttigieg et al., 2018). Recent realization of the power of the tools of molecular biology to detect minute amounts of an organism's DNA in seawater has led to processing of water samples to detect species (Thomsen et al., 2012) and even populations (Sigsgaard et al., 2016), however monitoring population size and trend from these data is a challenge that may prove difficult to overcome given differences in the rate of DNA loss between species and variable life spans of DNA in different environmental conditions (although see Thomsen et al., 2017). On the other hand, assessing kinship relationships through shared gene sequences has opened up a new method for estimating population size in challenging situations (Hillary et al., 2018).

Developing cost-effective biological sensors which can provide functional biodiversity information and using these on existing multiple observation platforms, will be a key challenge for the next 10 years. Setting goals and evaluating progress will be important to establish priorities and seeking support. The Biology and Ecosystems Panel is being supported through the PEGASuS Future Earth program to provide the scientific basis for such an evaluation.

\section{CONCLUSION}

"There is nothing a government hates more than to be wellinformed; for it makes the process of arriving at decisions much more complicated and difficult." - John Maynard Keynes, The Times (March 11, 1937); Collected Writings, vol. 21, p. 409.

Development of global ocean observing capacity for the biological EOVs is on the cusp of a step-change. Current capacity to make large numbers of diverse observations; to automate data processing; to integrate diverse data of known provenance in sophisticated, distributed and federated data systems that make data openly available as Findable, Accessible, Interoperable, and Reusable (FAIR) data; to produce openly available data products and visualizations; and to use robust cutting-edge modeling processes to "fill the gaps" in space and time where observations do not exist (e.g., Hill et al., 2017; Jansen et al., 2018), is certain to fundamentally alter the amount and quality of information and knowledge available to scientists and decision makers into the future. However, the coding and statistical skills required by the data scientists, data system software developers, and modelers, and in some cases the skills required by those responsible for the observations in the first place are considerable. It follows that explicit attention to training and capacity building must be a priority for the marine observation community if the activity of observation and resulting data are to have greatest impact at global scale.

There is little doubt that scientists will continue to expand their understanding of what lives in the ocean, where and how it is changing - it is a key driver for scientists' careers. However, whether this expanding information stream will inform policy and management processes is far harder to evaluate (Banks, 2018). An explicit evaluation of how scientific information contributes to national and international policy debate, and the governance mechanisms that could support an increased role, is essential as we move into the UN Decade and beyond. This will require the backing of political leaders, something that most scientists have little power to influence in their day to day jobs. A concerted effort by industry and scientists to work together with economists and other social scientists, a willingness by managers and policy makers to engage more fully in the scientific process, are needed to improve flows of relevant and timely, quality assured information and stimulate the integration of scientific information into the decision-making process. Coordination and collaboration between marine scientists to share their data openly and promptly thus providing consistent evidence-based messages is one of the few ways that scientists can raise the profile of scientific advice to our political leaders. But if we can achieve this, indicators or summary indicators that are used in decision making will become increasingly data-based and progressive, rather than yet one more review of previously reported information.

Recognizing these broader needs if we are to increase our effectiveness as marine scientists is one of the first steps toward achieving greater impact. As we move into the UN Decade we all need to make an additional effort to collaborate, coordinate and facilitate. In many cases it will require a cultural change in how we collect and share data, a change which the UN Decade is ideally situated to deliver. Members of the GOOS Biology and Ecosystems Panel are one of several groups working together to achieve greater output and impact from our ocean measurements, and we hope that you will join us.

\section{AUTHOR CONTRIBUTIONS}

$\mathrm{NB}, \mathrm{PM}$, and FM-K developed and wrote the manuscript. VA, SB, LB-C, PB, SC, DC, JD, DD, CJ, RK, DO, L-MR, Y-JS, $\mathrm{SS}, \mathrm{WA}$, and PT wrote the specific sections and reviewed the entire manuscript.

\section{FUNDING}

Components of this paper were developed at NCEAS as part of a Future Earth PEGASuS project. This work was supported in part by NASA grant NNX14AP62A "National Marine Sanctuaries as Sentinel Sites for a Demonstration Marine Biodiversity 
Observation Network (MBON)" to FM-K under the US National Ocean Partnership Program (NOPP RFP NOAA-NOS-IOOS2014-2003803 in partnership between NOAA, BOEM, and NASA), and the NOAA Integrated Ocean Observing System (IOOS) Program Office. NB was supported by the Australian Government's National Environmental Science Program (NESP)

\section{REFERENCES}

Abrahms, B., Scales, K. L., Hazen, E. L., Bograd, S. J., Schick, R. S., Robinson, P. W., et al. (2018). Mesoscale activity facilitates energy gain in a top predator. Proc. $R$. Soc. B Biol. Sci. 285:20181101. doi: 10.1098/rspb.2018.1101

Banks, G. (2018). Whatever Happened to 'Evidence Based Policy Making'? Alf Rattigan Lecture November 20, 2018. Canberra: Australia New Zealand School of Government.

Bar-On, Y. M., Phillips, R., and Milo, R. (2018). The biomass distribution on Earth. Proc. Natl. Acad. Sci. U.S.A. 115, 6506-6511. doi: 10.1073/pnas.1711842115

Battaile, B. C., and Trites, A. W. (2013). Linking reproduction and survival can improve model estimates of vital rates derived from limited time-series counts of pinnipeds and other species. PLoS One 8:e7738. doi: 10.1371/journal.pone. 0077389

Batten, S. D., Abu-Alhaija, R., Chiba, S., Edwards, M., Graham, G., Jyothibabu, R., et al. (2019). A global plankton diversity monitoring program. Front. Mar. Sci. 6:321. doi: 10.3389/fmars.2019.00321

Bax, N. J., Appeltans, W., Brainard, R., Duffy, J. E., Dunstan, P., Hanich, Q., et al. (2018). Linking capacity development to GOOS monitoring networks to achieve sustained ocean observation. Front. Mar. Sci. 5:346. doi: 10.3389/fmars. 2018.00346

Benson, A., Brooks, C. M., Canonico, G., Duffy, E., Muller-Karger, F., Sosik, H. M., et al. (2018). Integrated observations and informatics improve understanding of changing marine ecosystems. Front. Mar. Sci. 5:428. doi: 10.3389/fmars.2018. 00428

Beyer, H. L., Kennedy, E. V., Beger, M., Chen, C. A., Cinner, J. E., Darling, E. S., et al. (2018). Risk-sensitive planning for conserving coral reefs under rapid climate change. Conserv. Lett. 11:e12587. doi: 10.1111/conl.12587

Biller, S. J., Berube, P. M., Dooley, K., Williams, M., Satinsky, B. M., Hackl, T., et al. (2018). Marine microbial metagenomes sampled across space and time. Sci. Data 5:180176. doi: 10.1038/sdata.2018.176

Block, B. A., Jonsen, I. D., Jorgensen, S. J., Winship, A. J., Shaffer, S. A., Bograd, S. J., et al. (2011). Tracking apex marine predator movements in a dynamic ocean. Nature 475, 86-90. doi: 10.1038/nature10082

Boersma, P. D., and Rebstock, G. A. (2014). Climate change increases reproductive failure in Magellanic penguins. PLoS One 9:e85602. doi: 10.1371/journal.pone. 0085602

Borggaard, D. L., Gouveia, D. M., Colligan, M. A., Merrick, R., Swails, K. S., Asaro, M. J., et al. (2017). Managing U.S. Atlantic large whale entanglements: four guiding principles. Mar. Policy 84, 202-212. doi: 10.1016/j.marpol.2017.06.027

Boss, E., Waite, A., Muller-Karger, F., Yamazaki, H., Wanninkhof, R., Uitz, J., et al. (2018). Beyond chlorophyll fluorescence: the time is right to expand biological measurements in ocean observing programs. Limnol. Oceanogr. Bull. 27, 89-90. doi: $10.1002 /$ lob.10243

Bost, C. A., Cotte, C., Bailleul, F., Cherel, Y., Charrassin, J. B., Guinet, C., et al. (2009). The importance of oceanographic fronts to marine birds and mammals of the southern oceans. J. Mar. Syst. 78, 363-376. doi: 10.1016/j.jmarsys.2008. 11.022

Bourlat, S. J., Borja, A., Gilbert, J., Taylor, M. I., Davies, N., Weisberg, S. B., et al. (2013). Genomics in marine monitoring: New opportunities for assessing marine health status. Mar. Pollut. Bull. 74, 19-31. doi: 10.1016/j.marpolbul. 2013.05.042

Briscoe, D. K., Hobday, A. J., Carlisle, A., Scales, K., Eveson, J. P., Arrizabalaga, H., et al. (2017). Ecological bridges and barriers in pelagic ecosystems. Deep Sea Res. Part II Top. Stud. Oceanogr. 140, 182-192. doi: 10.1016/j.dsr2.2016.11.004

Brodie, S., Lédée, E. J. I., Heupel, M. R., Babcock, R. C., Campbell, H. A., Gledhill, D. C., et al. (2018). Continental-scale animal tracking reveals functional movement classes across marine taxa. Sci. Rep. 8:3717. doi: 10.1038/s41598018-21988-5
Marine Biodiversity Hub. PB acknowledges support from the Alfred Wegener Institute's Frontiers in Arctic Marine Monitoring Programme (FRAM) and the European Union's Horizon 2020 Research and Innovation Program under Grant Agreement No. 633211 (AtlantOS). This paper was conceived by the GOOS Biology and Ecosystems Panel.

Brown, B. L., Watson, M., Minot, S. S., Rivera, M. C., and Franklin, R. B. (2017). MinION ${ }^{\mathrm{TM}}$ nanopore sequencing of environmental metagenomes: a synthetic approach. GigaScience 6:gix007. doi: 10.1093/gigascience/gix007

Bruford, M. W., Davies, N., Dulloo, M. E., Faith, D. P., and Walters, M. (2017). "Monitoring Changes in Genetic Diversity," in The GEO Handbook on Biodiversity Observation Networks, eds M. Walters and R. Scholes (Cham: Springer).

Bunting, P., Rosenqvist, A., Lucas, R., Rebelo, L.-M., Hilarides, L., Thomas, N., et al. (2018). The Global Mangrove Watch - a new global baseline of mangrove extent. Remote Sens. 10:1669. doi: 10.3390/rs10101669

Burke, L., Reytar, K. A., Spalding, M. A., and Perry, A. L. (2011). Reefs at Risk. Washington, DC: World Resources Institute, 124.

Butler, C., Lucieer, V., Walsh, P., Flukes, E., and Johnson, C. (2017). Seamap Australia [Version 1.0] The Development of a National Benthic Marine Classification Scheme for the Australian Continental Shelf. Final Report to the Australian National Data Service (ANDS) High Values Collection \#19. Hobart: Institute for Marine and Antarctic Studies, University of Tasmania.

Buttigieg, P. L., Fadeev, E., Bienhold, C., Hehemann, L., Offre, P., and Boetius, A. (2018). Marine microbes in 4D using time series observation to assess the dynamics of the ocean microbiome and its links to ocean health. Curr. Opin. Microbiol. 43, 169-185. doi: 10.1016/j.mib.2018.01.015

Christiansen, F., Dujon, A. M., Sprogis, K. R., Arnould, J. P. Y., and Bejder, L. (2016). Noninvasive unmanned aerial vehicle provides estimates of the energetic cost of reproduction in humpback whales. Ecosphere 7:e01468. doi: $10.1002 /$ ecs 2.1468

Constable, A. J. (2011). Lessons from CCAMLR on the implementation of the ecosystem approach to managing fisheries. Fish Fish. 12, 138-151. doi: 10.1111/ j.1467-2979.2011.00410.x

Costa, D. P., Block, B. A., Bograd, S., Fedak, M. A., and Gunn, J. S. (2010). TOPP as a marine life observatory: using electronic tags to monitor the movements, behaviour and habitats of marine vertebrates. Proc. OceanObs 9, 21-25.

Costa, D. P., Breed, G. A., and Robinson, P. W. (2012). New Insights into pelagic migrations: implications for ecology and conservation. Annu. Rev. Ecol. Evol. Syst. 43, 73-96. doi: 10.1146/annurev-ecolsys-102710-145045

Crespo, G. O., and Dunn, D. C. (2017). A review of the impacts of fisheries on open-ocean ecosystems. ICES J. Mar. Sci. 74, 2283-2297. doi: 10.1098/rsbl.2015. 0976

Croll, D. A., Marinovic, B., Benson, S., Chavez, F. P., Black, N., Ternullo, R., et al. (2005). From wind to whales: trophic links in a coastal upwelling system. Mar. Ecol. Progr. Ser. 289, 117-130. doi: 10.3354/meps 289117

Cubaynes, H. C., Fretwell, P. T., Bamford, C., Gerrish, L., and Jackson, J. A. (2018). Whales from space: four mysticete species described using new VHR satellite imagery. Mar. Mammal Sci. 35, 466-491. doi: 10.1111/mms.12544

Davies, N., Field, D., Amaral-Zettler, L., Clark, M. S., Deck, J., Drummond, A., et al. (2014). The founding charter of the genomic observatories network. Gigascience 3:2. doi: 10.1186/2047-217X-3-2

De Pooter, D., Appeltans, W., Bailly, N., Bristol, S., Deneudt, K., Eliezer, M., et al. (2017). Toward a new data standard for combined marine biological and environmental datasets - expanding OBIS beyond species occurrences. Biodiver. Data J. 5:e10989. doi: 10.3897/BDJ.5.e10989

Descamps, S., Tarroux, A., Varpe, O., Yoccoz, N. G., Tveraa, T., and Lorentsen, S. H. (2015). Demographic effects of extreme weather events: snow storms, breeding success, and population growth rate in a long-lived Antarctic seabird. Ecol. Evol. 5, 314-325. doi: 10.1002/ece3.1357

Desprez, M., McMahon, C. R., Hindell, M. A., Harcourt, R., and Gimenez, O. (2013). Known unknowns in an imperfect world: incorporating uncertainty in recruitment estimates using multi-event capture-recapture models. Ecol. Evol. 3, 4658-4668. doi: 10.1002/ece3.846 
Doughty, C. E., Roman, J., Faurby, S., Wolf, A., Haque, A., Bakker, E. S., et al. (2016). Global nutrient transport in a world of giants. Proc. Natl. Acad. Sci. U.S.A. 113, 868-873. doi: 10.1073/pnas. 1502549112

Dubilier, N., McFall-Ngai, M., and Zhao, L. (2015). Microbiology: create a global microbiome effort. Nature 526, 631-634. doi: 10.1038/526631a

Ducklow, H. W., Fraser, W. R., Meredith, M. P., Stammerjohn, S. E., Doney, S. C., and Martinson, D. G. (2013). West Antarctic Peninsula: an icedependent coastal marine ecosystem in transition. Oceanography 26, 190-203. doi: 10.5670/oceanog.2013.62

Duffy, J. E., Benedetti-Cecchi, L., Trinanes, J. A., Muller-Karger, F. E., AmboRappe, R., and Boström, C. (2019). Toward a coordinated global observing system for seagrasses and marine macroalgae. Front. Mar. Sci. 6:317. doi: 10.3389/fmars.2019.00317

Duke, N. C., Kovacs, J. M., Griffiths, A. D., Preece, L., Hill, D. J. E., van Oosterzee, P., et al. (2017). Large-scale dieback of mangroves in Australia's Gulf of Carpentaria: a severe ecosystem response, coincidental with an unusually extreme weather event. Mar. Freshw. Res. 68, 1816-1829.

Dunstan, P. K., Bax, N. J., Dambacher, J. M., Hayes, K. R., Hedge, P. T., Smith, D. S., et al. (2016). Using ecologically or biologically significant marine areas (EBSAs) to implement marine spatial planning. Ocean Coast. Manag. 121, 116-127. doi: 10.1016/j.ocecoaman.2015.11.021

Dunstan, P. K., Foster, S. D., King, E., Risbey, J., O’Kane, T. J., Monselesan, D., et al. (2018). Global patterns of change and variation in sea surface temperature and chlorophyll a. Sci. Rep. 8:14624. doi: 10.1038/s41598-018-33057-y

Edgar, G. J., and Stuart-Smith, R. D. (2014). Systematic global assessment of reef fish communities by the reef life survey program. Sci. Data 1:140007. doi: $10.1038 /$ sdata.2014.7

Eriksen, M., Lebreton, L. C., Carson, H. S., Thiel, M., Moore, C. J., Borerro, J. C., et al. (2014). Plastic pollution in the world's oceans: more than 5 trillion plastic pieces weighing over 250,000 tons afloat at sea. PLoS One 9:e111913. doi: 10.1371/journal.pone.0111913

Estes, J. A., Heithaus, M., McCauley, D. J., Rasher, D. B., and Worm, B. (2016). Megafaunal impacts on structure and function of ocean ecosystems. Annu. Rev. Environ. Resour. 41, 83-116. doi: 10.1146/annurev-environ-110615-085622

Estes, J. A., Morissette, L., Smith, C., Costa, D., and McCarthy, J. (2014). Whales as marine ecosystem engineers. Front. Ecol. Environ. 12, 377-385.

FAO (2008). Loss of Mangroves Alarming. Rome: Food and Agriculture Organization of the United Nations.

Fretwell, P. T., LaRue, M. A., Morin, P., Kooyman, G. L., Wienecke, B., Ratcliffe, N., et al. (2012). An emperor penguin population estimate: The first global, synoptic survey of a species from space. PLoS One 7:e33751. doi: 10.1371/journal.pone. 0033751

Fretwell, P. T., Phillips, R. A., Brooke, A., Fleming, H., and McArthur, A. (2015). Using the unique spectral signature of guano to identify unknown seabird colonies. Remote Sens. Environ. 156, 448-456. doi: 10.1016/j.rse.2014. 10.011

Fretwell, P. T., Scofield, P., and Phillips, R. A. (2017). Using super-high resolution satellite imagery to census threatened albatrosses. IBIS 159, 481-490. doi: $10.1111 /$ ibi. 12482

Fretwell, P. T., Staniland, I. J., and Forcada, J. (2014). Whales from Space: counting Southern Right Whales by satellite. PLoS One 9:e88655. doi: 10.1371/journal. pone.0088655

GBIF (2018). Global Biodiversity Information Facility. Available at: https://www. gbif.org (accessed December 18, 2018).

GCRMN (2017). Value Proposition and Description of the Global Coral Reef Monitoring Network (GCRMN). Paris: IOC.

GCRMN (2018). GCRMN Implementation and Governance Plan. Monaco: International Coral Reef Initiative (ICRI).

Girard, C., Tucker, A. D., and Calmettes, B. (2009). Post-nesting migrations of loggerhead sea turtles in the Gulf of Mexico: dispersal in highly dynamic conditions. Mar. Biol. 156, 1827-1839. doi: 10.1007/s00227-009-1216-z

Goebel, M. E., Perryman, W. L., Hinke, J. T., Krause, D. J., Hann, N. A., Gardner, S., et al. (2015). A small unmanned aerial system for estimating abundance and size of Antarctic predators. Polar Biol. 38, 619-630. doi: 10.1007/s00300-0141625-4

Goetze, J. S., Bond, T., McLean, D. L., Saunders, B. J., Langlois, T. J., Lindfield, S., et al. (2019). A field and video analysis guide for diver operated stereo-video. Methods Ecol. Evol. 10, 1083-1090. doi: 10.1111/2041-210X.13189
Goodwin, K. D., Thompson, L. R., Duarte, B., Kahlke, T., Thompson, A. R., Marques, J. C., et al. (2017). DNA sequencing as a tool to monitor marine ecological status. Front. Mar. Sci. 4:107. doi: 10.3389/fmars.2017.00107

Grech, A., Chartrand-Miller, K., Erftemeijer, P., Fonseca, M., McKenzie, L., Rasheed, M., et al. (2012). A comparison of threats, vulnerabilities and management approaches in global seagrass bioregions. Environ. Res. Lett. 7:024006. doi: 10.1088/1748-9326/7/2/024006

Gutowsky, S. E., Tremblay, Y., Kappes, M. A., Flint, E. N., Klavitter, J., Laniawe, L., et al. (2014). Divergent post-breeding distribution and habitat associations of fledgling and adult Black-footed Albatrosses Phoebastria nigripes in the North Pacific. Ibis 156, 60-72. doi: 10.1111/ibi.12119

Harcourt, R., Sequeira, A. M. M., Zhang, X., Roquet, F., Komatsu, K., Heupel, M., et al. (2019). Animal-borne telemetry: an integral component of the ocean observing toolkit. Front. Mar. Sci. 6:326.

Harrison, A. L., Costa, D. P., Winship, A. J., Benson, S. R., Bograd, S. J., Antolos, M., et al. (2018). The political biogeography of migratory marine predators. Nat. Ecol. Evol. 2, 1571-1578. doi: 10.1038/s41559-018-0646-8

Hatfield, J. S. (2013). Population Dynamics of Hawaiian seabird colonies vulnerable to sea-level rise. Conserv. Biol. 27, 238-238. doi: 10.1111/j.1523-1739.2012. 01853.x

Hazen, E. L., Jorgensen, S., Rykaczewski, R. R., Bograd, S. J., Foley, D. G., Jonsen, I. D., et al. (2013). Predicted habitat shifts of Pacific top predators in a changing climate. Nat. Clim. Change 3, 234-238. doi: 10.1038/nclimate1686

Hildebrand, J. A., Baumann-Pickering, S., Frasier, K. E., Trickey, J. S., Merkens, K. P., Wiggins, S. M., et al. (2015). Passive acoustic monitoring of beaked whale densities in the Gulf of Mexico. Sci. Rep. 5:16343. doi: 10.1038/srep16343

Hill, N. A., Barrett, N., Ford, J. H., Peel, D., Foster, S., Lawrence, E., et al. (2018). Developing indicators and a baseline for monitoring demersal fish in data-poor, offshore Marine Parks using probabilistic sampling. Ecol. Indic. 89, 610-621. doi: 10.1016/j.ecolind.2018.02.039

Hill, N. A., Foster, S. D., Duhamel, G., Welsford, D., Koubb, I. P., and Johnson, C. R. (2017). Model-based mapping of assemblages for ecology and conservation management: a case study of demersal fish on the Kerguelen Plateau. Divers. Distrib. 23, 1216-1230. doi: 10.1111/ddi.12613

Hill, N. A., Lucieer, V., Barrett, N. S., Anderson, T. J., and Williams, S. B. (2014). Filling the gaps: predicting the distribution of temperate reef biota using high resolution biological and acoustic data. Estuar. Coast. Shelf Sci. 147, 137-147. doi: 10.1016/j.ecss.2014.05.019

Hillary, R. M., Bravington, M. V., Patterson, T. A., Grewe, P., Bradford, R., Feutry, P., et al. (2018). Genetic relatedness reveals total population size of white sharks in eastern Australia and New Zealand. Sci. Rep. 8:2661. doi: 10.1038/s41598018-20593-w

Hindell, M. A., McMahon, C. R., Bester, M. N., Boehme, L., Costa, D., Fedak, M. A., et al. (2016). Circumpolar habitat use in the southern elephant seal: implications for foraging success and population trajectories. Ecosphere 7:e01213. doi: $10.1002 /$ ecs 2.1213

Hughes, T. P., Kerry, J. T., Ãlvarez-Noriega, M., Ãlvarez-Romero, J. G., Anderson, K. D., Baird, A. H., et al. (2017). Global warming and recurrent mass bleaching of corals. Nature 543:373. doi: 10.1038/nature21707

Hussey, N. E., Kessel, S. T., Aarestrup, K., Cooke, S. J., Cowley, P. D., Fisk, A. T., et al. (2015). Aquatic animal telemetry: a panoramic window into the underwater world. Science 348:1255642. doi: 10.1126/science. 1255642

Hutchins, D. A., Fu, F., Sedwick, P. N., and Stehr, G. (2017). Microorganisms and ocean global change. Nat. Microbiol. 2:17058. doi: 10.1038/nmicrobiol.2017.58

Intergovernmental Panel on Climate Change (2018). Global Warming of $1.5^{\circ} \mathrm{C}$ : An IPCC Special Report on the Impacts of Global Warming of $1.5^{\circ} \mathrm{C}$ Above Pre-industrial Levels and Related Global Greenhouse Gas Emission Pathways, in the Context of Strengthening the Global Response to the Threat of Climate Change, Sustainable Development, and Efforts to Eradicate Poverty. Geneva: Intergovernmental Panel on Climate Change.

Jansen, J., Hill, N. A., Dunstan, P. K., McKinlay, J., Sumner, M. D., Post, A. L., et al. (2018). Abundance and richness of key Antarctic seafloor fauna correlates with modelled food-availability. Nat. Ecol. Evol. 2, 71-80. doi: 10.1038/s41559-0170392-3

Jennings, S., and Kaiser, M. J. (1998). The effects of fishing on marine ecosystems. Adv. Mar. Biol. 34, 201-352. doi: 10.1016/s0065-2881(08)60212-6

Kallmeyer, J., Pockalny, R., Adhikari, R. R., Smith, D. C., and D’Hondt, S. (2012). Global distribution of microbial abundance and biomass in subseafloor 
sediment. Proc. Natl. Acad. Sci. U.S.A. 109, 16213-16216. doi: 10.1073/pnas. 1203849109

Kirkman, S. P., Yemane, D., Oosthuizen, W. H., Meyer, M. A., Kotze, P. G. H., Skrypzeck, H., et al. (2013). Spatio-temporal shifts of the dynamic Cape fur seal population in southern Africa, based on aerial censuses (19722009). Mar. Mammal Sci. 29, 497-524. doi: 10.1111/j.1748-7692.2012. 00584.x

Kopf, A., Bicak, M., Kottmann, R., Schnetzer, J., Kostadinov, I., Lehmann, K., et al. (2015). The ocean sampling day consortium. Gigascience 4:27. doi: 10.1186/ s13742-015-0066-5

Koslow, J. A., Boehlert, G. W., Gordon, J. D. M., Haedrich, R. L., Lorance, P., and Parin, N. (2000). Continental slope and deep-sea fisheries: implications for a fragile ecosystem. ICES J. Mar. Sci. 57, 548-557. doi: 10.1006/jmsc.2000. 0722

Krause, D. J., Hinke, J. T., Perryman, W. L., Goebel, M. E., and LeRoi, D. J. (2017). An accurate and adaptable photogrammetric approach for estimating the mass and body condition of pinnipeds using an unmanned aerial system. PLoS One 12:20. doi: 10.1371/journal.pone. 0187465

Kusel, E. T., Munoz, T., Siderius, M., Mellinger, D. K., and Heimlich, S. (2017). Marine mammal tracks from two-hydrophone acoustic recordings made with a glider. Ocean Sci. 13, 273-288. doi: 10.5194/os-13-273-2017

LaRue, M. A., Rotella, J. J., Garrott, R. A., Siniff, D. B., Ainley, D. G., Stauffer, G. E., et al. (2011). Satellite imagery can be used to detect variation in abundance of Weddell seals (Leptonychotes weddellii) in Erebus Bay, Antarctica. Polar Biol. 34, 1727-1737. doi: 10.1007/s00300-011-1023-0

LaRue, M. A., Stapleton, S., and Anderson, M. (2017). Feasibility of using highresolution satellite imagery to assess vertebrate wildlife populations. Conserv. Biol. 31, 213-220. doi: 10.1111/cobi.12809

Lent, R., and Squires, D. (2017). Reducing marine mammal bycatch in global fisheries: An economics approach. Deep Sea Res. Part II Top. Stud. Oceanogr. 140, 268-277. doi: 10.1016/j.dsr2.2017.03.005

Levin, L. A., Bett, B. J., Gates, A. R., Helmbach, P., Howe, B. M., Janssen, F., et al. (2019). Global observing needs in the deep ocean. Front. Mar. Sci. 6:241. doi: $10.3389 /$ fmars.2019.00241

Lewison, R., Wallace, B., Alfaro-Shigueto, J., Mangel, J. C., Maxwell, S. M., and Hazen, E. L. (2013). "Fisheries bycatch of marine turtles," in Lessons Learned From Decades of Research and Conservation Biology of Sea Turtles, Vol III, eds J. Wyneken, K. J. Lohmann, and J. A. Musick (Boca Raton, FL: CRC Press).

Lindstrom, E., Gunn, J., Fischer, A., McCurdy, L. K., and Glover, A. (2012). A Framework for Ocean Observing. IOC Information Document - 1284. Paris: UNESCO.

Lombard, F., Boss, E., Waite, A. M., Vogt, M., Uitz, J., Stemmann, L., et al. (2019). Globally consistent quantitative observations of planktonic ecosystems. Front. Mar. Sci. 6:196. doi: 10.3389/fmars.2019.00196

MacIntyre, K. Q., Stafford, K. M., Conn, P. B., Laidre, K. L., and Boveng, P. L. (2015). The relationship between sea ice concentration and the spatio-temporal distribution of vocalizing bearded seals (Erignathus barbatus) in the Bering, Chukchi, and Beaufort Seas from 2008 to 2011. Progr. Oceanogr. 136, 241-249. doi: $10.1016 /$ j.pocean.2015.05.008

McCauley, D. J., Pinsky, M. L., Palumbi, S. R., Estes, J. A., Joyce, F. H., and Warner, R. R. (2015). Marine defaunation: animal loss in the global ocean. Science 347:1255641. doi: 10.1126/science. 1255641

McQuillan, J. S., and Robidart, J. C. (2017). Molecular-biological sensing in aquatic environments: recent developments and emerging capabilities. Curr. Opin. Biotechnol 45, 43-50. doi: 10.1016/j.copbio.2016.11.022

Miloslavich, P., Bax, N. J., Simmons, S. E., Klein, E., Appeltans, W., AburtoOropeza, O., et al. (2018a). Essential ocean variables for global sustained observations of biodiversity and ecosystem changes. Glob. Change Biol. 24, 2416-2433. doi: $10.1111 /$ gcb. 14108

Miloslavich, P., Seeyave, S., Muller-Karger, F., Bax, N., Ali, E., Delgado, C., et al. (2018b). Challenges for global ocean observation: the need for increased human capacity. J. Operat. Oceanogr. 1-20. doi: 10.1080/1755876X.2018.152 6463

Miloslavich, P., Pearlman, J., and Kudela, R. (2018c). Sustainable Observations of Plankton, the Sea's Food Foundation. Available at: https://eos.org/meetingreports/sustainable-observations-of-plankton-the-seas-food-foundation (accessed November 11, 2018)
Monk, J., Barrett, N., Bridge, T., Carroll, A., Friedman, A., Jordan, A., et al. (2018). Marine Sampling Field Manual for AUV's (Autonomous Underwater Vehicles). Canberra: NESP Marine Biodiversity Hub.

Moore, J. E., and Barlow, J. P. (2013). Declining abundance of beaked whales (family Ziphiidae) in the California Current large marine ecosystem. PLoS ONE 8:e52770. doi: 10.1371/journal.pone.0052770

Moore, J. E., Wallace, B. P., Lewison, R. L., Zydelis, R., Cox, T. M., and Crowder, L. B. (2009). A review of marine mammal, sea turtle and seabird bycatch in USA fisheries and the role of policy in shaping management. Mar. Policy 33, 435-451. doi: 10.1016/j.marpol.2008.09.003

Moran, M. A. (2015). The global ocean microbiome. Science 80:8455. doi: 10.1126/ science.aac 8455

Moss, B. (2017). Marine reptiles, birds and mammals and nutrient transfers among the seas and the land: an appraisal of current knowledge. J. Exp. Mar. Biol. Ecol. 492, 63-80. doi: 10.1016/j.jembe.2017.01.018

Muller-Karger, F. E., Kavanaugh, M. Y., Montes, E., Balch, W. M., Breitbart, M., Chavez, F. P., et al. (2014). A framework for a marine biodiversity observing network within changing continental shelf seascapes. Oceanography 27, 18-23. doi: 10.5670/oceanog.2014.56

Muller-Karger, F. E., Hestir, E., Ade, C., Turpie, K., Roberts Dar, A., Siegel, D., et al. (2018a). Satellite sensor requirements for monitoring essential biodiversity variables of coastal ecosystems. Ecol. Appl. 28, 749-760. doi: 10.1002/eap. 1682

Muller-Karger, F. E., Miloslavich, P., Bax, N. J., Simmons, S., Costello, M. J., Sousa Pinto, I., et al. (2018b). Advancing marine biological observations and data requirements of the complementary essential Ocean variables (EOVs) and essential biodiversity variables (EBVs) frameworks. Front. Mar. Sci. 5:211. doi: 10.3389/fmars.2018.00211

Munger, L., Lammers, M. O., Cifuentes, M., Würsig, B., Jefferson, T. A., and Hung, S. K. (2016). Indo-Pacific humpback dolphin occurrence north of Lantau Island, Hong Kong, based on year-round passive acoustic monitoring. J. Acoust. Soc. Am. 140, 2754-2765. doi: 10.1121/1.4963874

Nordlund, L. M., Koch, E. W., Barbier, E. B., and Creed, J. C. (2016). Seagrass ecosystem services and their variability across genera and geographical regions. PLoS One 11:e0163091. doi: 10.1371/journal.pone.0163091

Pardo, D., Jenouvrier, S., Weimerskirch, H., and Barbraud, C. (2017). Effect of extreme sea surface temperature events on the demography of an agestructured albatross population. Philos. Trans. R. Soc. B-Biol. Sci. 372:20160143. doi: 10.1098/rstb.2016.0143

Patricio, J., Little, S., Mazik, K., Papadopoulou, K.-N., Smith, C. J., Teixeira, H., et al. (2016). European marine biodiversity monitoring networks: strengths, weaknesses, opportunities and threats. Front. Mar. Sci. 3:161.

Pauly, D., Hilborn, R., and Branch, T. A. (2013). Fisheries: does catch reflect abundance? Nature 494, 303-306. doi: 10.1038/494303a

Peckham, S. H., Maldonado-Diaz, D., Tremblay, Y., Ochoa, R., Polovina, J., and Balazs, G. (2011). Demographic implications of alternative foraging strategies in juvenile loggerhead turtles Caretta caretta of the North Pacific Ocean. Mar. Ecol. Progr. Ser. 425, 269-280. doi: 10.3354/meps08995

Pereira, H. M., Ferrier, S., Walters, M., Geller, G. N., Jongman, R. H. G., Scholes, R. J., et al. (2013). Essential biodiversity variables. Science 339, 277-278.

Pesant, S., Grigorov, I., Malfatti, F., Magalhães, C., Vezzi, A., Poulain, J., et al. (2017). EMOSE (2017) Inter-Comparison of Marine Plankton Metagenomic Analysis Methods. Charlottesville, VA: OSF.

Poloczanska, E. S., Brown, C. J., Sydeman, W. J., Kiessling, W., Schoeman, D. S., Moore, P. J., et al. (2013). Global imprint of climate change on marine life. Nat. Clim. Chang. 3, 919-925. doi: 10.1038/nclimate1958

Proud, R., Handegard, N. O., Kloser, R., Cox, M., and Brierley, A. S. (2018). From siphonophores to deep scattering layers: uncertainty ranges for the estimation of global mesopelagic fish biomass. ICES J. Mar. Sci. 76, 718-733. doi: 10.1093/ icesjms/fsy037

Prowe, A. F., Pahlow, M., Dutkiewicz, S., Follows, M., and Oschlies, A. (2012). Topdown control of marine phytoplankton diversity in a global ecosystem model. Progr. Oceanogr. 101, 1-13. doi: 10.1016/j.pocean.2011. 11.016

Przeslawski, R., Foster, F., Monk, J., Barrett, N., Bouchet, P., Carroll, A. G., et al. (2019). A suite of field manuals for marine sampling to monitor Australian waters. Front. Mar. Sci. 6:177. doi: 10.3389/fmars.2019.00177 
Reid, K., Croxall, J., Briggs, D. R., and Murphy, E. J. (2005). Antarctic ecosystem monitoring: quantifying the response of ecosystem indicators to variability in Antarctic krill. ICES J. Mar. Sci. 62, 366-373. doi: 10.1016/j.icesjms.2004.11.003

Rhein, M., Rintoul, S. R., Aoki, S., Campos, E., Chambers, D., Feely, R. A., et al. (2013). Observations: Ocean in Climate Change 2013: The Physical Science Basis. Contribution of Working Group I to the Fifth Assessment Report of the Intergovernmental Panel on Climate Change. Cambridge: Cambridge University Press.

Roelfsema, C., Kovacs, E., Roos, P., Terzano, D., Lyons, M., and Phinn, S. (2018). Use of a semi-automated object based analysis to map benthic composition, Heron Reef, Southern Great Barrier Reef. Remote Sens. Lett. 9, 324-333. doi: 10.1080/2150704x.2017.1420927

Roman, J., Estes, J. A., Morissette, L., Smith, C., Costa, D., McCarthy, J., et al. (2014). Whales as marine ecosystem engineers. Front. Ecol. Environ. 12, 377-385.

Romanach, S. S., DeAngelis, D. L., Koh, H. L., Li, Y., Teh, S. Y., Raja Barizan, R. S., et al. (2018). Conservation and restoration of mangroves: global status, perspectives, and prognosis. Ocean Coast. Manag. 154, 72-82. doi: 10.1016/j. ocecoaman.2018.01.009

Roquet, F., Williams, G., Hindell, M. A., Harcourt, R., McMahon, C., Guinet, C., et al. (2014). A Southern Indian Ocean database of hydrographic profiles obtained with instrumented elephant seals. Sci. Data 1:140028. doi: 10.1038/ sdata.2014.28

Rotella, J. J., Link, W. A., Chambert, T., Stauffer, G. E., and Garrott, R. A. (2012). Evaluating the demographic buffering hypothesis with vital rates estimated for Weddell seals from 30 years of mark-recapture data. J. Anim. Ecol. 81, 162-173. doi: 10.1111/j.1365-2656.2011.01902.x

Rusch, D. B., Halpern, A. L., Sutton, G., Heidelberg, K. B., Williamson, S., Yooseph, S., et al. (2007). The Sorcerer II Global Ocean Sampling expedition: northwest Atlantic through eastern tropical Pacific. PLoS Biol. 5:e77.

Schmidtko, S., Stramma, L., and Visbeck, M. (2017). Decline in global oceanic oxygen content during the past five decades. Nature 542, 335-339. doi: 10.1038/ nature21399

Scholin, C., Birch, J., Jensen, S., Marin, R., Massion, E., Pargett, D., et al. (2017). The quest to develop ecogenomic sensors: A 25-year history of the environmental sample processor (ESP) as a case study. Oceanography 30, 100-113. doi: 10.5670/oceanog.2017.427

Sczyrba, A., Hofmann, P., Belmann, P., Koslicki, D., Janssen, S., Dröge, J., et al. (2017). Critical assessment of metagenome interpretation-a benchmark of metagenomics software. Nat. Methods 14:1063. doi: 10.1038/nmeth. 4458

Sequeira, A. M. M., Rodríguez, J. P., Eguíluz, V. M., Harcourt, R., Hindell, M., Sims, D. W., et al. (2018). Convergence of marine megafauna movement patterns in coastal and open oceans. Proc. Natl. Acad. Sci. U.S.A. 115, 3072-3077. doi: $10.1073 /$ pnas. 1716137115

Shin, Y.-J., Bundy, A., Shannon, L. J., Blanchard, J., Chuenpagdee, R., Knight, B., et al. (2012). Global in scope and regionally rich: an IndiSeas workshop helps shape the future of marine ecosystem indicators. Rev. Fish Biol. Fish. 22, 835-845. doi: 10.1007/s11160-012-9252-Z

Sigsgaard, E. E., Nielsen, I. B., Bach, S. S., Lorenzen, E. D., Robinson, D. P., and Knudsen, S. W. (2016). Population characteristics of a large whale shark aggregation inferred from seawater environmental DNA. Nat. Ecol. Evol. 1:4. doi: 10.1038/s41559-016-0004

Širovic, A., Rice, A., Chou, E., Hildebrand, J. A., Wiggins, S. M., and Roch, M. A. (2015). Seven years of blue and fin whale call abundance in the Southern California Bight. Endanger. Spec. Res. 28, 61-76. doi: 10.3354/ esr00676

Southwell, C., Bengtson, J., Bester, M., Blix, A. S., Bornemann, H., Boveng, P., et al. (2012). A review of data on abundance, trends in abundance, habitat use and diet of ice-breeding seals in the Southern Ocean. CCAMLR Sci. 19, 49-74.

Southwell, C., Emmerson, L., Takahashi, A., Barbraud, C., Delord, K., and Weimerskirch, H. (2017). Large-scale population assessment informs conservation management for seabirds in Antarctica and the Southern Ocean: a case study of Adelie penguins. Glob. Ecol. Conserv. 9, 104-115. doi: 10.1016/j. gecco.2016.12.004

Stall, S., Yarmey, L., Cutcher-Gershenfeld, J., Hanson, B., Lernhert, K., Nosek, B., et al. (2019). Make scientific data FAIR'. Nature 570, 27-29. doi: 10.1038/ d41586-019-01720-7
Stock, C. A., John, J. G., Rykaczewski, R. R., Asch, R. G., Cheung, W. W. L., Dunne, J. P., et al. (2017). Reconciling fisheries catch and ocean productivity. Proc. Natl. Acad. Sci.U.S.A. 114, E1441-E1449. doi: 10.1073/pnas. 1610238114

Sunagawa, S., Coelho, L. P., Chaffron, S., Kultima, J. R., Labadie, K., Salazar, G., et al. (2015). Structure and function of the global ocean microbiome. Science 348, 1261359-1261359. doi: 10.1126/science.126 1359

Suryan, R. M., Anderson, D. J., Shaffer, S. A., Roby, D. D., Tremblay, Y., Costa, D. P., et al. (2008). Wind, waves, and wing loading: morphological specialization may limit range expansion of endangered albatrosses. PLoS One 3:e4016. doi: 10.1371/journal.pone.0004016

Tew Kai, E., Rossi, V., Sudre, J., Weimerskirch, H., Lopez, C., Hernandez-Garcia, E., et al. (2009). Top marine predators track Lagrangian coherent structures. Proc. Natl. Acad. Sci. U.S.A. 106, 8245-8250. doi: 10.1073/pnas.08110 34106

Thompson, L. R., Sanders, J. G., McDonald, D., Amir, A., Ladau, J., Locey, K. J., et al. (2017). A communal catalogue reveals earth's multiscale microbial diversity. Nature 551, 457-463. doi: 10.1038/nature24621

Thomsen, P. F., Kielgast, J., Iversen, L. L., Moller, P. R., Rasmussen, M., and Willerslev, E. (2012). Detection of a diverse marine fish fauna using environmental DNA from seawater samples. PLoS One 7:e41732. doi: 10.1371/ journal.pone.0041732

Thomsen, P. F., Moller, P. R., Sigsgaard, E. E., Knudsen, S. W., Jorgensen, O. A., and Willerslev, E. (2017). Environmental DNA from seawater samples correlate with trawl catches of Subarctic. Deepwater Fishes. PLoS One 11:e0165252. doi: 10.1371/journal.pone.0165252

Thorne, L. H., Conners, M. G., Hazen, E. L., Bograd, S. J., Antolos, M., Costa, D. P., et al. (2016). Effects of El Nino-driven changes in wind patterns on North Pacific albatrosses. J. R. Soc. Interface 13:20160196. doi: 10.1098/rsif.2016. 0196

Thresher, R. E., Tilbrook, B., Fallon, S. J., Wilson, N. C., and Adkins, J. (2011). Effects of chronic low carbonate saturation levels on the distribution, growth and skeletal chemistry of deep-sea corals and other seamount megabenthos. Mar. Ecol. Prog. Ser. 442, 87-99. doi: 10.3354/meps 09400

Tompkins, E. M., Townsend, H. M., and Anderson, D. J. (2017). Decadal-scale variation in diet forecasts persistently poor breeding under ocean warming in a tropical seabird. PLoS One 12:e182545. doi: 10.1371/journal.pone. 0182545

Trathan, P. N., Fretwell, P. T., and Stonehouse, B. (2011). First Recorded Loss of an Emperor Penguin Colony in the Recent Period of Antarctic Regional Warming: Implications for Other Colonies. PLoS One 6:e14738. doi: 10.1371/journal.pone. 0014738

Treasure, A. M., Roquet, F., Ansorge, I. J., Bester, M. N., Boehme, L., Bornemann, H., et al. (2017). Marine mammals exploring the oceans pole to pole a review of the MEOP consortium. Oceanography 30, 132-138. doi: 10.5670/oceanog. 2017.234

Tynan, C. T. (1998). Ecological importance of the Southern Boundary of the Antarctic Circumpolar Current. Nature 392, 708-710. doi: 10.1002/ece3. 2833

Unsworth, R., Nordlund, L. M., and Cullen-Unsworth, L. C. (2018). Seagrass meadows support global fisheries production. Conserv. Lett. 8:e12566. doi: $10.1111 /$ conl.12566

van Hooidonk, R., Maynard, J., Tamelander, J., Gove, J., Ahmadia, G., Raymundo, L., et al. (2016). Local-scale projections of coral reef futures and implications of the Paris Agreement. Sci. Rep. 6:39666. doi: 10.1038/srep39666

Wallace, B. P., DiMatteo, A. D., Bolten, A. B., Chaloupka, M. Y., Hutchinson, B. J., Abreu-Grobois, F. A., et al. (2011). Global conservation priorities for marine turtles. PLoS One 6:e24510. doi: 10.1371/journal.pone.0024510

Watson, R. A., Pitcher, T. J., and Jennings, S. (2017). Plenty more fish in the sea? Fish Fish. 18, 105-113. doi: 10.1111/faf.12128

Waycott, M., Duarte, C. M., Carruthers, T. J., Orth, R. J., Dennison, W. C., Olyarnik, S., et al. (2009). Accelerating loss of seagrasses across the globe threatens coastal ecosystems. Proc. Natl. Acad. Sci. U.S.A. 106, 12377-12381. doi: 10.1073/pnas.0905620106

Weimerskirch, H., Bouard, F., Ryan, P. G., and Bost, C. A. (2018). Massive decline of the world's largest king penguin colony at Ile aux 
Cochons, Crozet. Antarct. Sci. 30, 236-242. doi: 10.1017/s095410201800 0226

Weimerskirch, H., Guionnet, T., Martin, J., Shaffer, S. A., and Costa, D. (2000). Fast and fuel efficient? Optimal use of wind by flying albatrosses. Proc. R. Soc. Lond. B Biol. Sci. 267, 1869-1874. doi: 10.1098/rspb.2000.1223

Weimerskirch, H., Louzao, M., de Grissac, S., and Delord, K. (2012). Changes in wind pattern alter albatross distribution and life-history traits. Science 335, 211-214. doi: 10.1126/science. 1210270

Wilkinson, C. (ed.) (2000). Status of Coral Reefs of the World: 2000. Townsville: Australian Institute of Marine Science.

Wilkinson, C. (ed.) (2008). Status of Coral Reefs of the World: 2008. Townsville: Australian Institute of Marine Science.

Williams, A., Schlacher, T. A., Rowden, A. A., Althaus, F., Clark, M. R., Bowden, D. A., et al. (2010). Seamount megabenthic assemblages fail to recover from trawling impacts. Mar. Ecol. 31, 183-199. doi: 10.1111/j.14390485.2010.00385.x
World Meteorological Organization [WMO] (2016). The Global Observing System for Climate: Implementation Needs. Geneva: World Meteorological Organization.

Conflict of Interest Statement: The authors declare that the research was conducted in the absence of any commercial or financial relationships that could be construed as a potential conflict of interest.

Copyright (c) 2019 Bax, Miloslavich, Muller-Karger, Allain, Appeltans, Batten, Benedetti-Cecchi, Buttigieg, Chiba, Costa, Duffy, Dunn, Johnson, Kudela, Obura, Rebelo, Shin, Simmons and Tyack. This is an open-access article distributed under the terms of the Creative Commons Attribution License (CC BY). The use, distribution or reproduction in other forums is permitted, provided the original author(s) and the copyright owner(s) are credited and that the original publication in this journal is cited, in accordance with accepted academic practice. No use, distribution or reproduction is permitted which does not comply with these terms. 